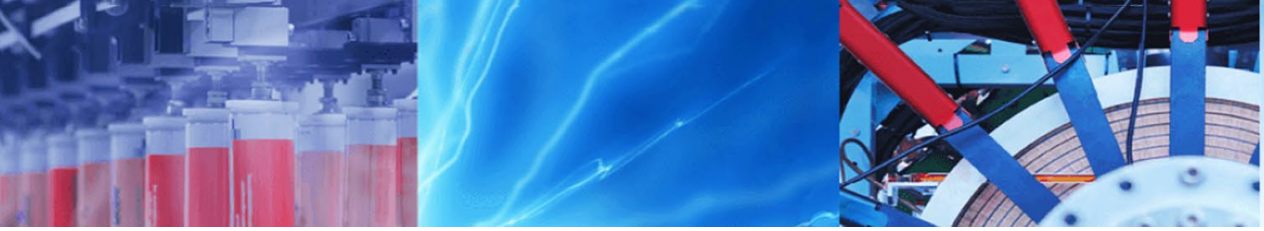

Research Article

\title{
GIS-based spatial prediction of landslide susceptibility using frequency ratio model of Lachung River basin, North Sikkim, India
}

\author{
Subodh Chandra Pal ${ }^{1} \cdot$ Indrajit Chowdhuri ${ }^{2}$
}

(c) Springer Nature Switzerland AG 2019

\begin{abstract}
Landslide causes damage to property and life in the Himalayan region as well as Sikkim Himalaya. Landslide susceptibility assessment is very important to mark out the landslide susceptibility area, and researchers take some plans for the future. Landslide susceptibility map has become essential to identify the landslide-prone zones and to find out the probable causes of a landslide in an area. The main objectives of this study are to produce landslide susceptibility mapping by frequency ratio method and to find out the dominant parameters which are responsible for the occurrences of frequent landslide in Lachung River basin, the main tributary of Teesta River in Sikkim Himalaya. The study utilized different types of data which include geological data, advanced spaceborne thermal emission and reflection radiometer-based digital elevation model, Sentinel-2A sensor data, published thematic map and precipitation data, and all data have been processed with the help of remote sensing and GIS tools. Ten influential causative factors of landslide occurrence are used for the susceptibility assessment, and they are slope angle, slope aspect, elevation, profile curvature, land use/land cover, normalized differences vegetation index, drainage density, road density, geology and rainfall. The GIS-based landslide susceptibility analysis has been discussed with ten dominant factors by using frequency ratio model. Finally, the landslide susceptibility map was classified into very high (0.591\%), high (1.867\%), moderately high (5.172\%), moderate (19.682\%), moderately low (25.685\%), low (29.816\%) and very low (17.187\%). The map was compared with the validation of landslide location, and the model was verified by the receiver operating characteristic curve. The results revealed $88.9 \%$ prediction rate and $92.3 \%$ success rate, which means this model is validated with landslide susceptibility analysis in the study area.
\end{abstract}

Keywords Frequency ratio method $\cdot$ Landslide susceptibility $\cdot$ ROC curve

\section{Introduction}

In the present time, our natural environment faces a number of destructive natural hazards such as earthquake, flood, drought, storm surge and landslide all over the world. All these geo-environmental hazards have brought the beleful footprint over the earth. Landslide is known as a natural hazard in hill and mountainous areas all over the world, and it has effect on the life of the people in hill region in general and traffic in particular. Landslide is a type of mass movement, and it is the rapid fall of the large volume of rocks and soils from upslope to downslope mainly because of gravity [1]. Landslide is renowned as a mountainous disaster and responsible for massive economic and social losses [2]. A huge amount of economic losses, injuries and death are caused by landslide, nearly about 18,414 people died, 4.8 million people were affected and 8 billion US\$ resources were damaged in the period of 1998-2017 all over the world [3]. Landslide is a semimajor disaster in India and hit lives, infrastructure, roads, communication and resources in the hill region. In India, $12.6 \%$ of total area is landslide-prone area therein, about

$\checkmark$ Subodh Chandra Pal, geo.subodh@gmail.com; Indrajit Chowdhuri, indrajitchowdhuri@gmail.com | ${ }^{1}$ Department of Geography, The University of Burdwan, Burdwan, West Bengal 713104, India. ${ }^{2}$ Department of Geography, Visva-Bharati, Santiniketan, West Bengal 731235, India. 
$43 \%$ is captured by Darjeeling-Sikkim Himalaya region, about $33 \%$ is covered by northwest Himalaya, $22 \%$ area is acquired by western hill, Konkan Ghat, and about $2 \%$ area is captured by eastern hill, Aruku (https://www.gsi.gov. in). To show the distractive power landslide and reduce divesting power of landslide, researchers considered different approaches of methodology on our globe [4]. From the past, researchers and planners are divided landslide studies into two parts, pre-disaster and post-disaster study. Landslide susceptibility analysis is a pre-disaster management which deals with the past landslide data and dominant factors of landslide occurrence. Terminologically, landslide susceptibility mapping (LSM) is used to categorize land surface into areas and to arrange them according to the degree of vulnerability of different causative factors. According to Varnes [5], prediction of landslide is a complicated process over space and time but an area may be divided into homogeneous zones according to the probability of landslide occurrences, which is called landslide susceptibility analysis. First of all, researchers identify which reasons or factors have caused landslide in an area. Slope instability causes landslide which is determined by numerous contributory factors broadly such as topography, geology, geomorphology, climatic, hydrology and anthropogenic factors [6-8]. Earthquakeinduced landslides are significant threats of the mountain areas [9]. Most of these landslides have been caused by slope failure and construction of roads and highway [10]. An increase in population and many modern economic activities are the causes of landslide in a mountainous region. Landslide susceptibility is very useful to planner and developer because susceptibility assessment helps to recognize the vulnerable places and also reveal which factor is more active for this mountainous hazard [11]. The study of landslide is of world interest mainly due to the increasing consciousness of socioeconomic impacts of landslide and the increasing pressure of urbanization [12].

The LSM study has been carried out to divide the land surface into zones of varying degrees of stability based on the estimated significance of individual causative factors to initiate instability of landslide [13]. Researchers carried out the LSM by the different factors and different parameters. Over the decades, numbers of approaches have been used to evaluate the method of landslide susceptibility based on remote sensing (RS) and geographical information system (GIS). Throughout the world, GIS-based landslide susceptibility analyses have first been introduced by different researchers considering different factors [12, 14-16]. The techniques of landslide susceptibility analysis are divided into three types which are considered by many researchers, and these are the deterministic, heuristic and statistical methods $[17,18]$. Most of the studies have conducted heuristic and statistical methods because those methods are fitted for evaluating the susceptibility analysis. In the heuristic technique, the factors have got weight and rank according to their importance in causing slope failure and the weight are assigning based on specialists, such as spatial multi-criteria evolution (analytical hierarchy process and weighted linear combination) and fuzzy logic approach $[8,19-22]$. Statistical methods are based on the account of slope failure and causes for future under the same condition which had occurred in the past and present conditions [18]; these methods are divided into two types, bivariate (frequency ratio, weight of evidence, information value, etc.) and multivariate (logistic regression, artificial neural network, etc.). The main differences between these methods depend on the given value of numerical weight for the causative factors of landslides [23]. Frequency ratio model [24-26], weight of evidence model $[27,28]$ and information value method $[29,30]$ are important for spatial prediction of landslide occurrence, and these models are based on the relationship between the distribution of landslide and each of the landsliderelated factors. Many researchers have applied logistic regression [10, 31-33] and artificial neural network [34,35] which have a relationship between a dependent variable and several independent variables. Except this systematically known statistical method, different kinds of mathematical methods have been applied by the researcher, which are generalized additive model (GAM), Shannon entropy algorithm with fuzzy membership functions, random subspace (RS), Naïve Bayes trees (NBT), support vector machine (SVM), evidential belief function (EBF), certainty factor (CF), index of entropy (IOE), random forest $(\mathrm{RF})$, Bayes net (BN), radical basis function (RBF), logistic model tree (LMT), etc. [36-42]. Many authors used two or more scientific statistical methods ensemble for landslide susceptibility and LSM. Chen et al. [43] used WOF, EBF, logistic tree model (LTM) and an ensemble of LTM with WOF and EBF models for flood susceptibility, and the result showed EBF-LMT has better prediction than other models. Shahabi et al. [44] applied FR, AHP and LR methods for LSM and the models have well predicted whether LR model has the high prediction value. Now quantitative analyses of geomorphological parameters have been performed by principal component analysis (PCA) in a scientific research such as landslide vulnerability [45]. PCA is a statistical method used to reduce a large number of interrelated variables to a smaller number of dominant variables for landslide occurrence or landslide susceptibility [46]. Landslide is a primary destructive hazard in Himalayan and Nilgiri mountainous regions. Various methods have been applied for landslide hazard analysis in the Himalayas as well as Sikkim Himalaya, including GIS-based, heuristic and statistical methods [2, 25, 30,47-49]. Anbalagan et al. [47] attempted landslide susceptibility mapping with the 
help of statistical and heuristic methods in the Lachung valley, North Sikkim.

The study area, Lachung River basin in North Sikkim district, has a very steep slope and unfavorable geological and environmental conditions, causing the natural hazards such as landslide. Landslide is a natural phenomenon, so it cannot be fully controlled, but we can minimize loss of life and property if it is predicted well in advance and identify the landslide vulnerable areas. The main objectives of this research are to analyze the given landslide conditioning factors in a microlevel, to identify the landslide susceptibility zones through susceptibility mapping which would be developed by frequency ratio, RS and GIS techniques and to amplify the acceptance of landslide susceptibility method and maps for landslide mitigation planning of local administers.

\subsection{Study area}

Geographically the study area is located in northeastern Sikkim, India, and lies between latitudes $27^{\circ} 34^{\prime} 00^{\prime \prime}-27^{\circ} 59^{\prime} 10^{\prime \prime}$ north and longitudes $88^{\circ} 38^{\prime} 20^{\prime \prime}-88^{\circ} 53^{\prime} 15^{\prime \prime}$ east (Fig. 1). The total geographical area is about $760.52 \mathrm{sq}$. km. Lachung River basin of Sikkim Himalaya is geologically and tectonically young folded mountain with humid climates, seasonally high rainfall and highly steep and dynamic landscape of the world. The hill tops in the north are covered with permanent snow which feeds the Lachung, Lachen and Teesta tributaries. The altitude ranges from 1583 to $6824 \mathrm{~m}$. Highest temperature $\left(20^{\circ} \mathrm{C}\right)$ is recorded in July and lowest $\left(-13^{\circ} \mathrm{C}\right)$ temperature is recorded in January. The above $6000 \mathrm{~m}$ altitudes showed excessive low temperature $\left(-40^{\circ} \mathrm{C}\right)$. Heavy monsoon rainfalls are found in May to September (1795 mm in 2017) in the southern part, and the northern part gets precipitation through snowfall except June and July. The climate of the study area varies from subtropical to alpine in different seasons. Tectonically, this area is active folded mountain belt and this area belongs to seismic zone IV, so earthquake is a common incident. The geological formations are under Cenozoic era which is symbolized undifferentiated intrusive rocks of tourmaline, pegmatite, biotite leucogranite, etc. Proterozoic era represents undifferentiated intrusive of metamorphic rocks, i.e., amphibolites, schist, mica schist, biotite schist, graphite schist, granite gneiss, quartzite, etc. The gneiss and schist rocks mostly occupied the area. Due to the unfavorable physical conditions, Sikkim faced such catastrophic landslides in recent decades [50]. Apart from the ruinous landslide, many microscale slope failures were unreported in Lachung basin because it occurred in the remote part of hill. Earthquake-induced landslide occurred in September 18, 2011, all over Sikkim as well as in Lachung basin, and landslide occurred right from Himalayan foothill to high range [51]. On June 5, 2012, and March 29, 2013, roadside landslide attacked some parts of Lachung basin which causes cutoff of road, blockage of stranded tourist and death of habitants (https ://www.hindustantimes.com; https://www.telegraphindia. com; https://www.indiatvnews.com). On September 14 and 15, 2018, rain-induced landslide occurred and the road linked between Lachung valley and district headquarters of North Sikkim has been cutoff (https://www. ndtv.com). The population density of North Sikkim district is 11 per sq. km, but millions of tourists can travel to North Sikkim (Lachung and surroundings) and tourists can have mesmerizing experience of mountainous beauty. Landslide is a serious concern for the local people and tourist.

\section{Database and methodology}

\subsection{Data preparation}

A variety of research techniques were used for the improvement in landslide susceptibility analysis. The landslide areas were marked out by the visual interpretation of Google image 2002-2018 and field survey (April 2018) with the help of global positioning system (GPS). Topographic factors including slope angle, slope aspect, elevation, curvature and drainage network were mainly produced from advanced spaceborne thermal emission and reflection radiometer (ASTER)-based digital elevation model (DEM; $30 \mathrm{~m}$ spatial resolution and acquisition date: October 17, 2011) which have been derived from https:// earthexplorer.usgs.gov using GIS environment. The land use/land cover map was produced from Sentinel-2A sensor data (10 $\mathrm{m}$ spatial resolutions) which was acquired in June 4, 2017 (Raw 33 and Path 45), with the help of GIS environment by supervised classification. Normalized difference vegetation index (NDVI) or vegetation index map was made by image processing in GIS environment. Geology, road and rainfall data were taken from published data [52]. All maps were geo-referenced and projected by universal transverse mercator (UTM-45/N) using the World Geodetic System (WGS 1984) with the cell size of $30 \mathrm{~m} \times 30 \mathrm{~m}$. Table 1 shows the different types of data. To understand the total methodology, methodological flow chart has been drawn (Fig. 2)

\subsubsection{Database of landslide inventory}

Most important data source of landslide susceptibility analysis is the historical data of landslide, and this type of data is called landslide inventory which can be produced 


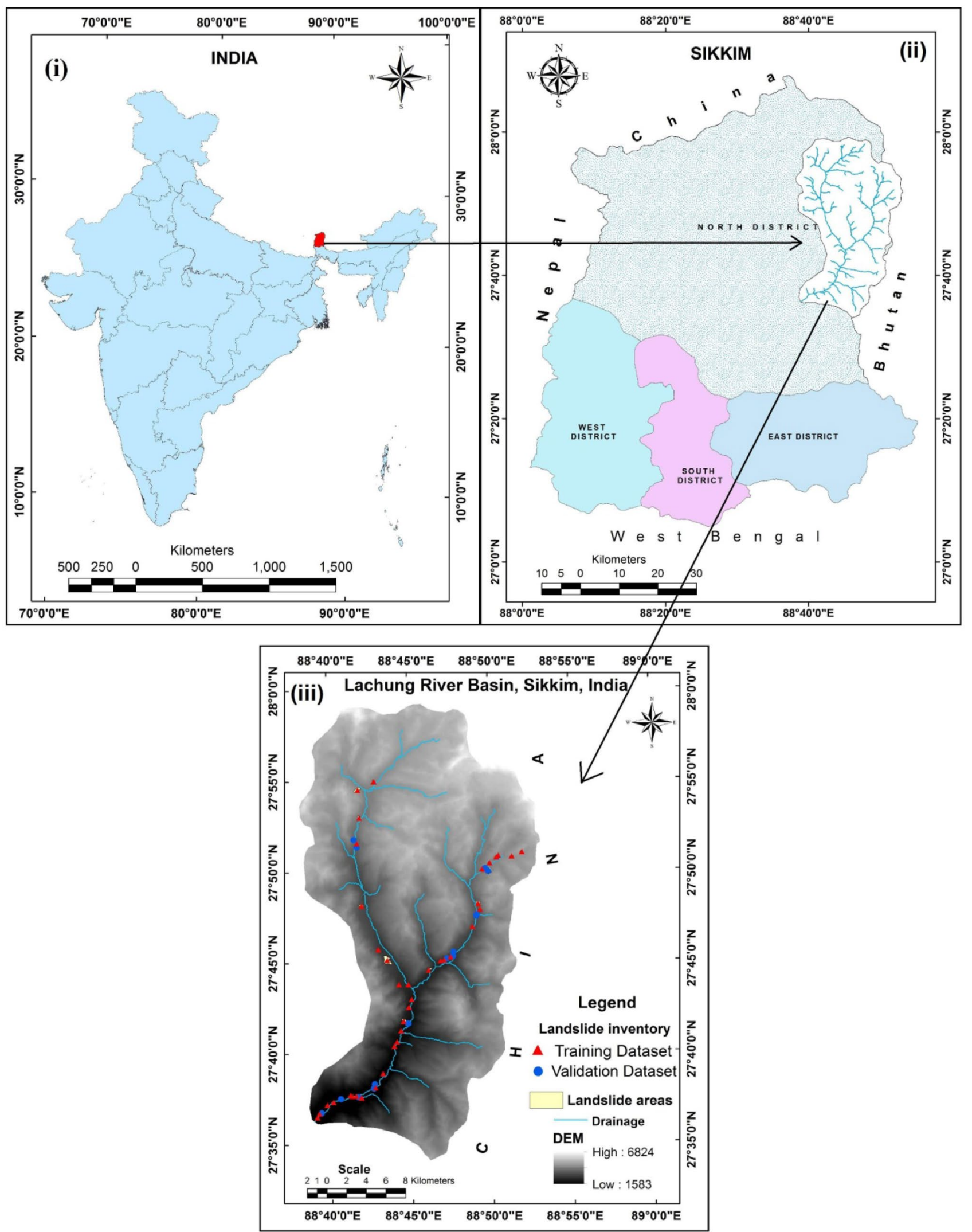

Fig. 1 Location of the study area 


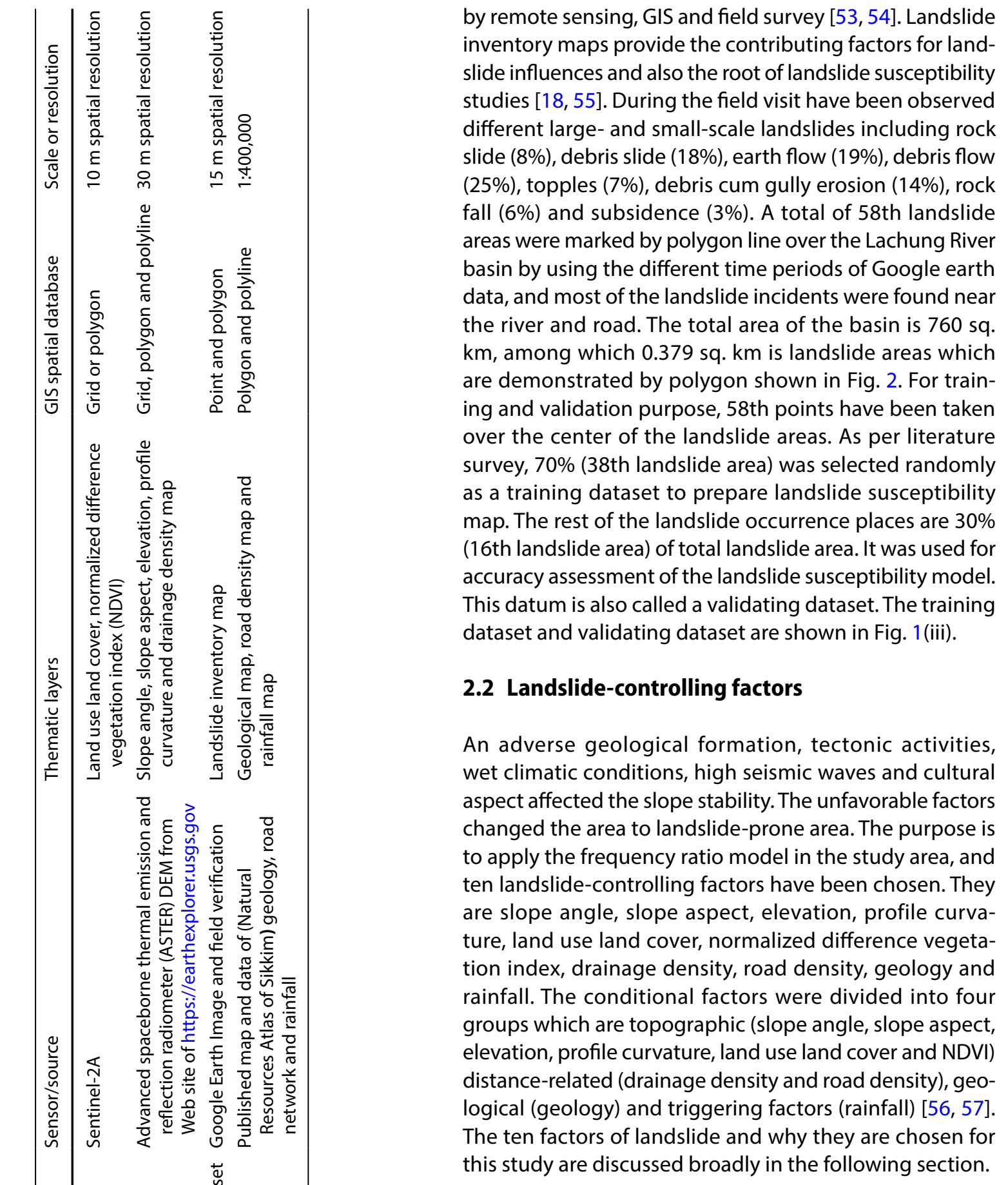

\subsubsection{Topographic factors}

Frequency and intensity of landslide depend upon stability and instability of a slope. The magnitude of landslides is maximum when the slope angle is between $35^{\circ}$ and $40^{\circ}$ and it is minimum when the slope is greater than $40^{\circ}$ [58]. Slope configuration and steepness are played a vital role in contact with lithology [11]. Slope angle map has been subcategorized into seven classes considering the angle of the slope by natural breaks (Jenks) method (Fig. 3). In physical 
Fig. 2 Methodological flow chart

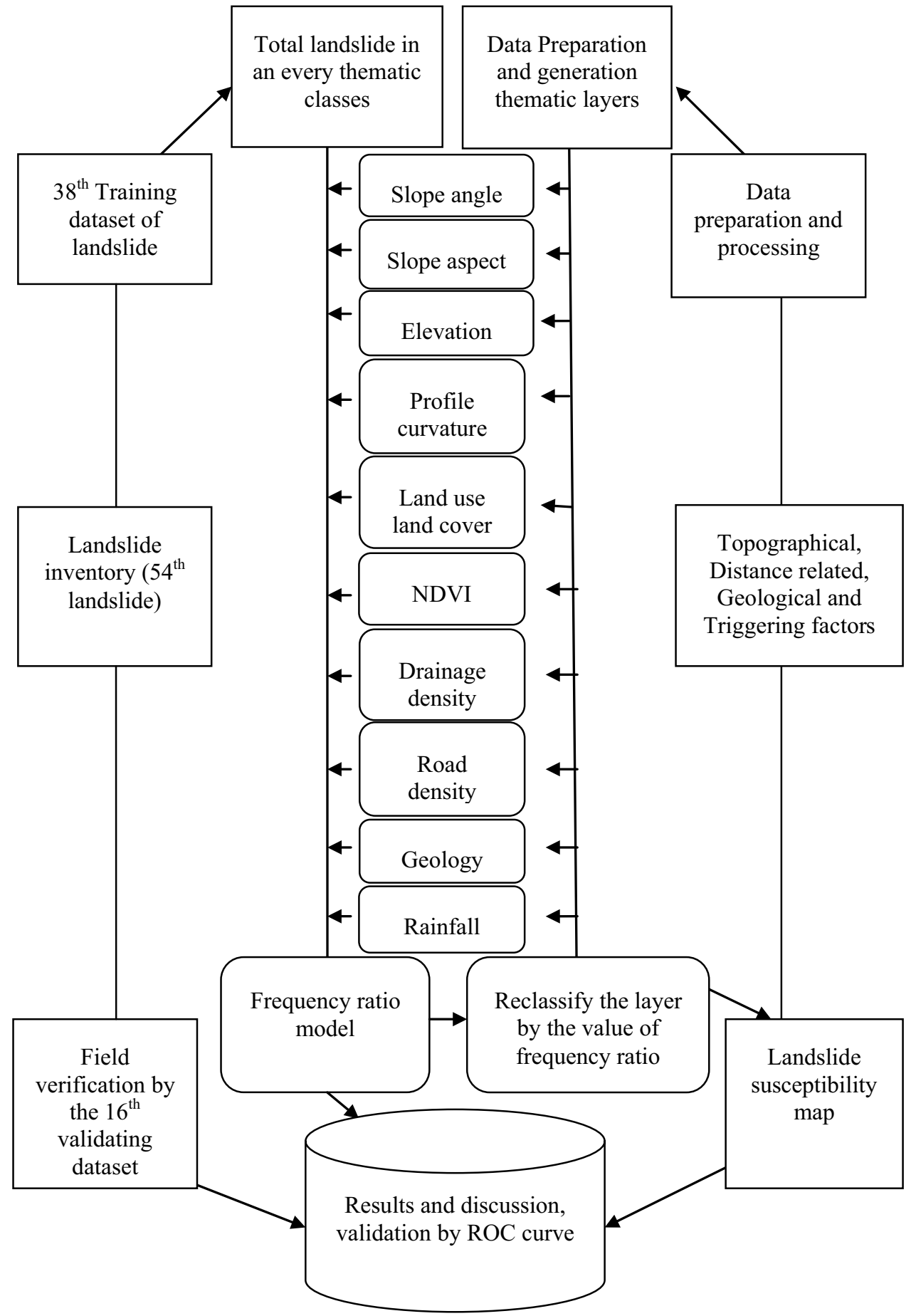

geography, slope aspect is the compass direction of slope face. South, east, southeast and southwest are more active slope faces for the occurrence of weathering and erosion process in Sikkim Himalaya. Slope aspect regions are classified into nine categories according to the slope aspect (Fig. 4). Elevation is another significant conditioning for landslide susceptibility mapping because researchers have pointed out the increase rate of frequency and magnitude of landslide at the higher elevation $[59,60]$. In the study area, elevation was classified into seven different categories by natural breaks (Jenks) method (Fig. 5). Curvature is a way to measure roughness of a slope. Parallel to the direction of the maximum slope is called profile curvature. These are two types, concave $(+1<)$ and convex $(-1<)$. Profile curvature affects the acceleration and deceleration of downslope flows, which is the result of erosional and 
Fig. 3 Slope angle map

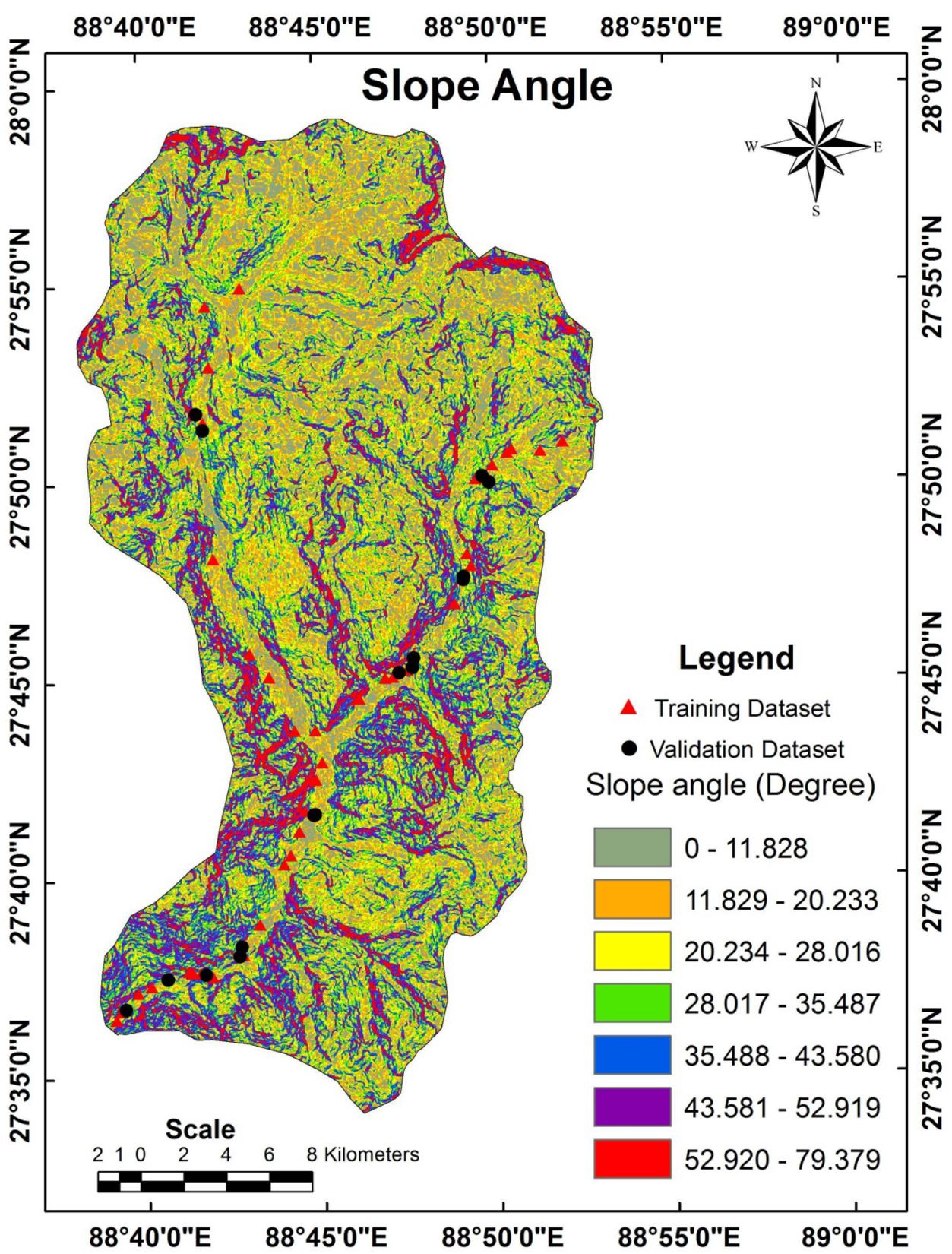

depositional work that causes landslide $[32,61]$. The profile curvature map has been classified into seven classes by natural breaks (Jenks) method (Fig. 6). The land use/ land cover (LULC) map is one of the important controlling factors for landslide occurrence because mass wasting depends on the types of land [8]. Preprocessing Sentinel2A satellite image (Raw 33 and Path 45) has been collected on June 04,2017 , and land use/land cover map was prepared by using supervised classification tool in advance of GIS environment. The road network and river network have superimposed on the classified map. From the ground survey, five classes have been taken and represented the different land cover types that include forest, grassland, barren land, snowmelt area and snowfield area (Fig. 7). The normalized difference vegetation index (NDVI) is a determinant parameter for landslide, which reveals the quantity and intensity of vegetation in a image [62].The formula of NDVI had been developed by Kriegler et al. [63]. NDVI is calculated by Eq. (1).

$\mathrm{NDVI}=((\mathrm{NIR}-\mathrm{R}) /(\mathrm{NIR}+\mathrm{R}))$

where $I R=$ pixel value of infrared band (band 3 for Sentinel-2A) and $R=$ pixel value of the red band (band 4 for Sentinel-2A). The Sentinel-2A image (Raw 33 and Path 
Fig. 4 Slope aspect map

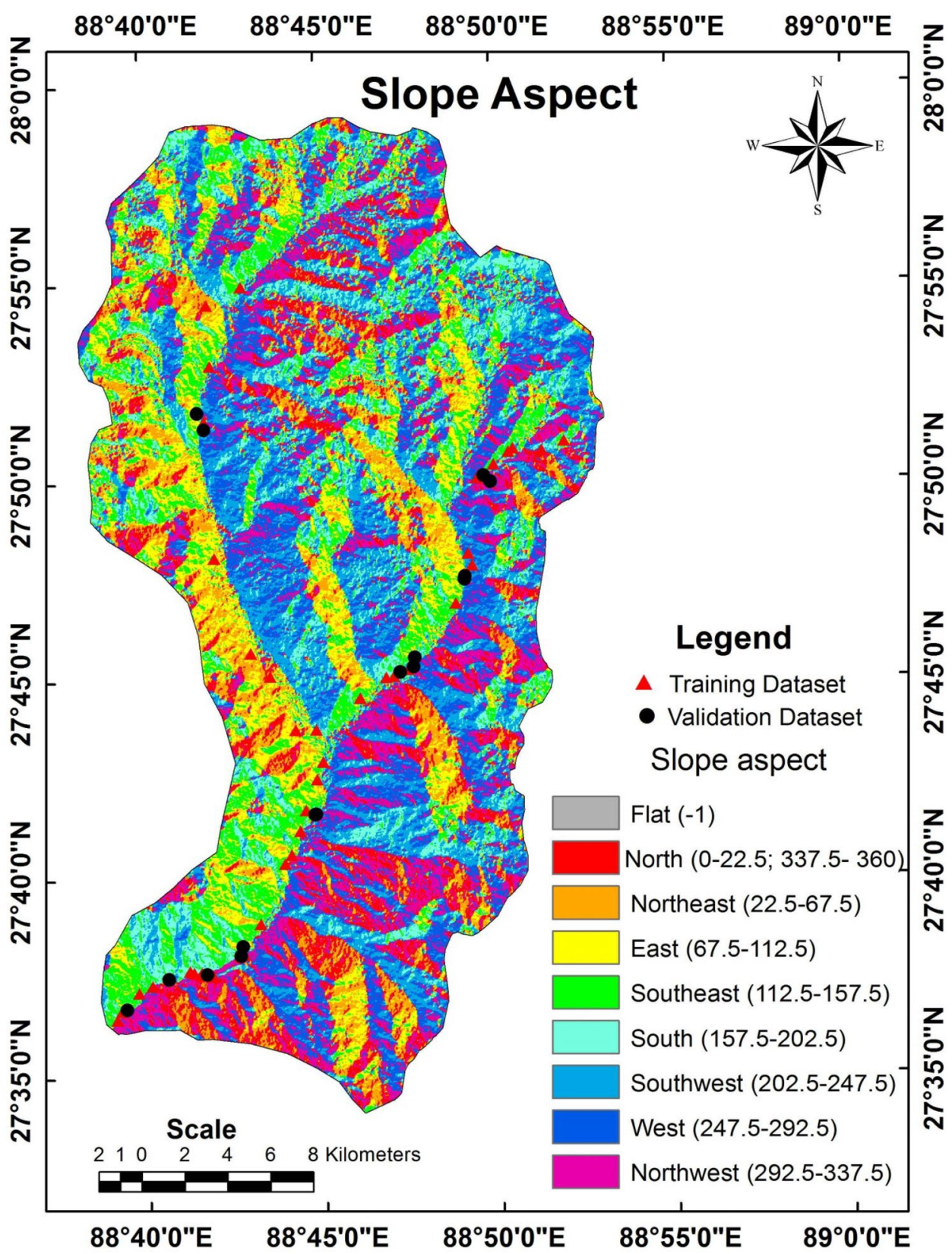

45) has been used for extraction of vegetation index map with the help of GIS environment. The NDVI value varies between -1.0 and 1.0. The negative value represented cloud, water and snow. The value is near zero found in the exposed rock, barren land and sand. Moderate values represented shrub and grassland, while high NDVI value indicated the high dense forest [56]. The landslide occurrence is very low in dense forest area [28]. In the study area, the NDVI map is categorized into seven subgroups by natural breaks (Jenks) method (Fig. 8).

\subsubsection{Distance-related factors}

Drainage density was calculated by the total length of drainage divided by the total area. Erosional power of a river, flooding and groundwater condition have been determined by the drainage density. It has been observed in many researches that the probability of slope failures is larger when the drainage density is higher $[19,41]$. Streams have a negative effect on mass movement because saturated land and bank erosion reduced the shear strength of slope causing the landslide. [48, 64]. Drainage segments of Lachung basin were extracted from DEM and took streams for drainage density (Kernel density), and density 
Fig. 5 Elevation map

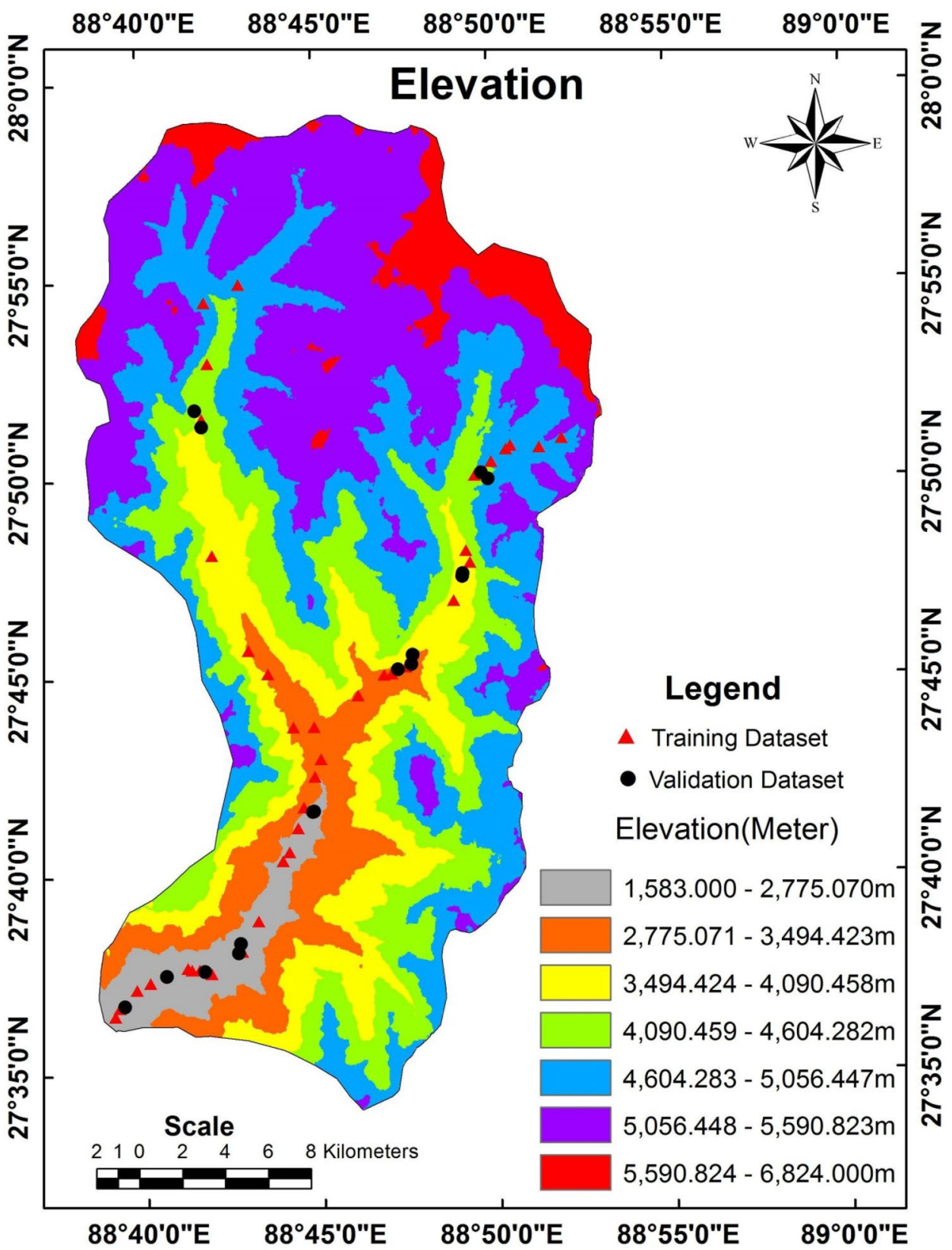

was divided into seven subclasses (Fig. 9). Road construction over the mountainous region has a negative impact on landslide. Road construction has created a very steep slope in the toe of the hills which disturbs the stability of natural topography and affects the stability of the slope also [65]. Road density is an effective measure of influence of road over landslide occurrences. In these concerns, road networks have taken from the previously published work and road density has been generated by kernel line density method in GIS environment. The road density map has been divided into seven subclasses (Fig. 10).

\subsubsection{Geological factor}

Geology is the most determinant factor of landslide. Weak and undifferentiated structure of lithology increased the rate of landslide [66]. The rocks of the river basins are grouped into Chungthang Formation, Kanchenjunga Gneiss and Darjeeling Gneiss Formation, amphibole schist/ amphibolite basic intrusive and tourmaline/biotite intrusive in the Lachung River basin area (Fig. 11). A detailed description of geological formation of the study area is given in Table 2. 
Fig. 6 Profile curvature map

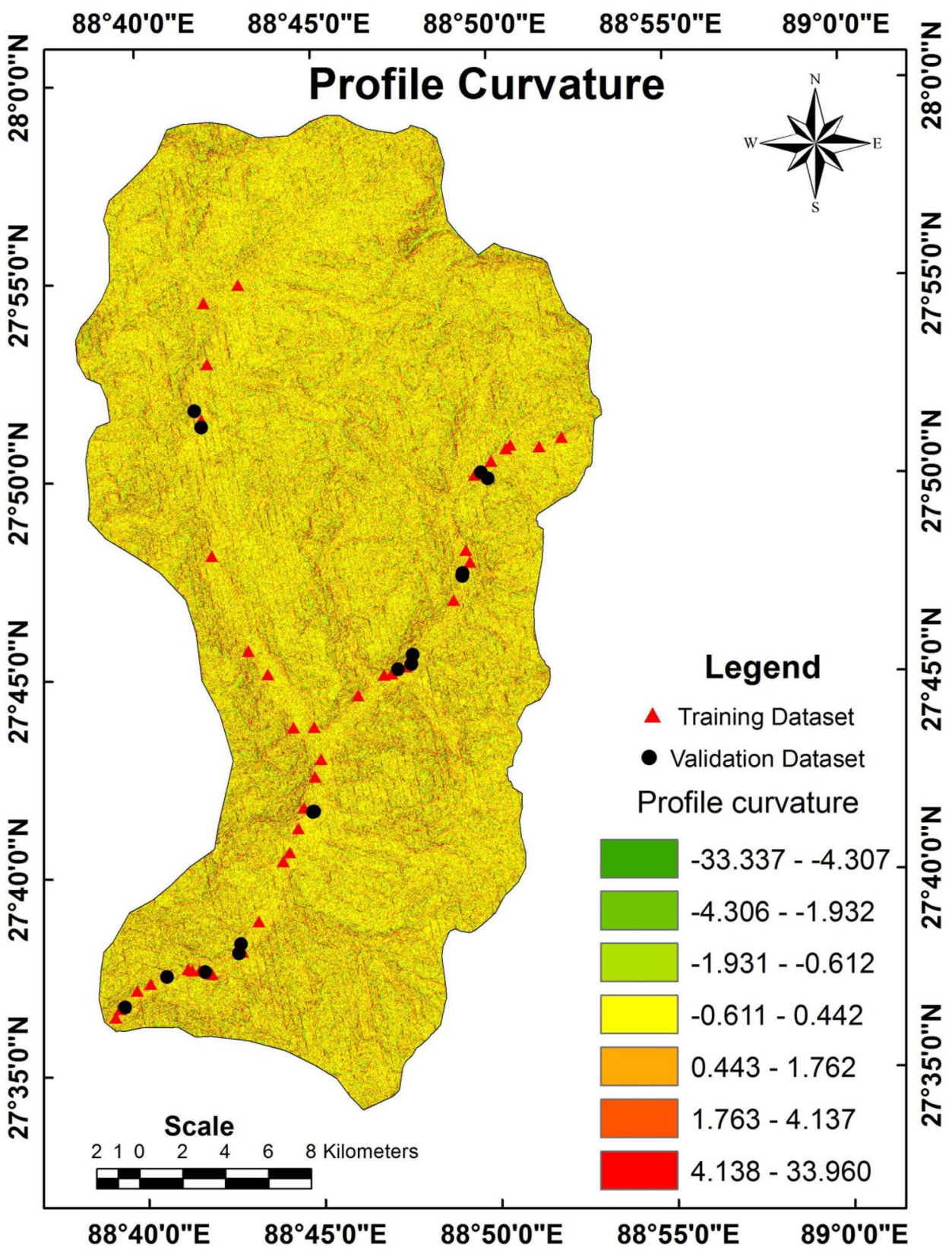

\subsubsection{Triggering factors}

The rainfall is a triggering factor for landslides and closely associated with landslide tendency [32]. The destructive power or magnitude of landslide was increased by the heavy rainfall. The annual rainfall of the study area has been prepared by inverse distance weighting (IDW) method and classified into seven classes by the natural breaks (Jenks) methods (Fig. 12). Monthly precipitation data from 1901 to 2018 of North Sikkim have been shown in rainfall dispersion diagram where agglomeration of average monthly rainfall has been shown in every bar graph (Fig. 13).

\subsection{Frequency ratio method}

The ratio of the presence and absence of hazards (landslide, flood) can be used for landslide susceptibility assessment $[26,55]$. Frequency ratio model is a bivariate statistical analysis which analyzes the landslide events and landslideassociated factors for landslide susceptibility analysis [24]. Frequency ratio model is based on the connection between distribution of landslide and each of the landslide-related 
Fig. 7 Land use and land cover map

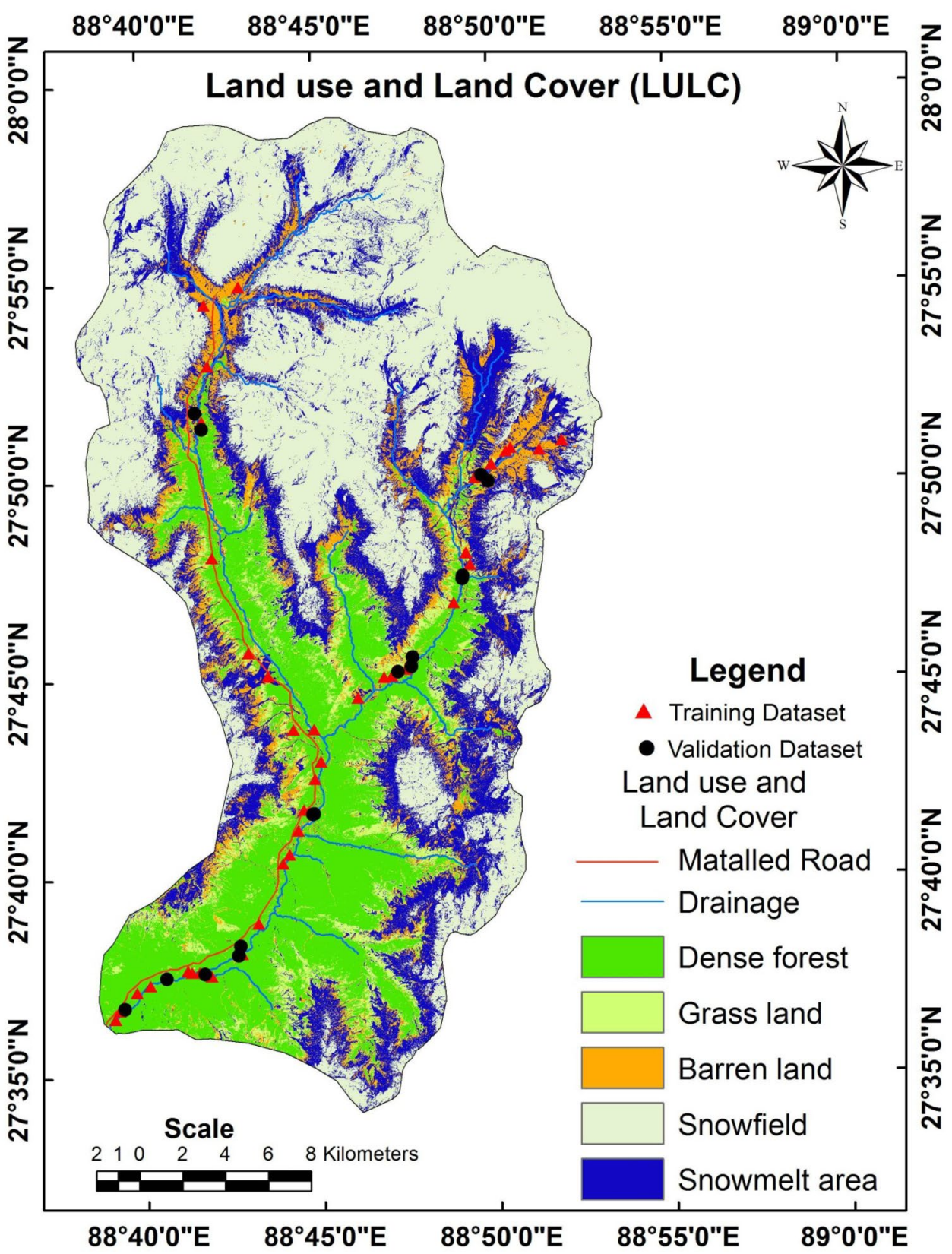

factors [25]. Therefore, the frequency ratios of each factor's categories were calculated from their relationship with landslide area as given in Table 3. Frequency ratio value comes from the ratio between the percentage of landslide pixel and percentage of entire area pixel in each and every factor's classes [67]. The value is greater than 1, which means higher correlation, and the value is lower than 1 , which means lower correlation between factors classes and landslide occurrence [25]. The frequency ratio has been calculated using Eq. (2).
$\mathrm{FR}=\frac{\left(\mathrm{NLS}_{\mathrm{pix}} / \sum_{\mathrm{i}=1}^{\mathrm{n}} \mathrm{NLS}_{\mathrm{pix}}\right) * 100}{\left(\mathrm{NC}_{\mathrm{pix}} / \sum_{\mathrm{i}=1}^{\mathrm{n}} \mathrm{NC}_{\mathrm{pix}}\right) * 100}$

where $\mathrm{FR}=$ frequency ratio value, $\mathrm{NLS}_{\mathrm{pix}}=$ number of land slide pixel in a class of a factor, $\sum_{\mathrm{i}=1}^{\mathrm{n}} \mathrm{NLS}$ pix $=$ sum of all landslide pixels in the entire area, $\mathrm{NC}_{\text {pix }}=$ number of pixel in a class of a factor and $\sum_{i=1}^{n} N C_{p i x}=$ sum of all pixel class in the entire area. First of all, factor maps were prepared. 
Fig. 8 Normalized difference vegetation index (NDVI) map

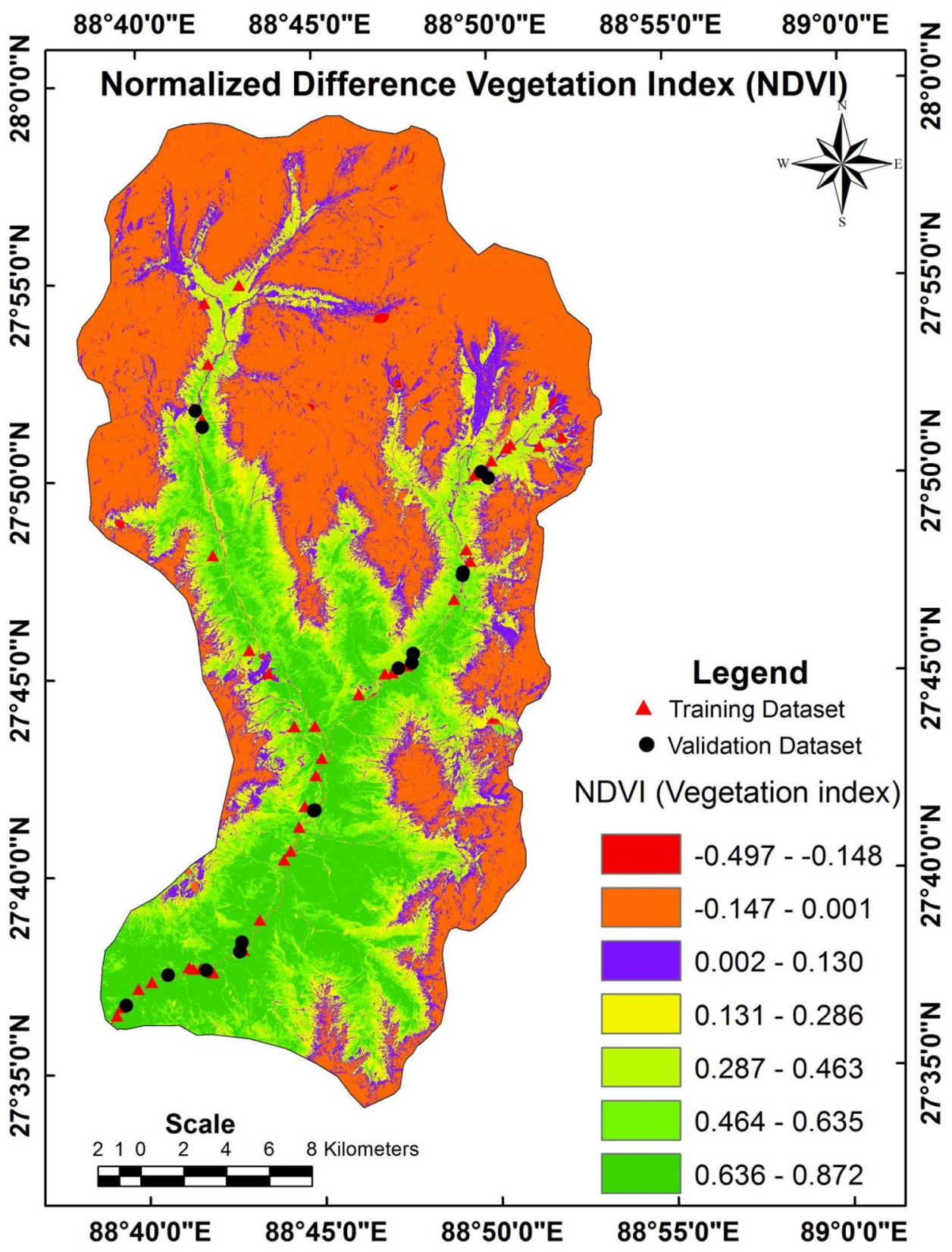

Frequency ratio values have been acquired by the frequency ratio method, and then factor map is regenerated by assigning the weight of frequency ratio value of each class. At last, all factors layers are overlaid considering weight of frequency ratio value using Eq. (3) and created landslide susceptibility index map (Fig. 2).

Landslide susceptibility index

$$
\begin{aligned}
& =\left(F r \_S A+F r \_S A s+F r \_E l+F r \_P C\right. \\
& +\mathrm{Fr} \_ \text {LULC + Fr_NDVI + Fr_DD } \\
& \left.+\mathrm{Fr} \_\mathrm{RD}+\mathrm{Fr} \_\mathrm{Ge}+\mathrm{Fr} \_\mathrm{Ra}\right)
\end{aligned}
$$

where $\mathrm{Fr}=$ value of frequency ratio, $\mathrm{Fr} \_\mathrm{SA}=$ value of slope angle, $\mathrm{Fr} \_\mathrm{SAs}=$ value of slope aspect, $\mathrm{Fr} \_\mathrm{El}=$ value of elevation, $\mathrm{Fr} \_\mathrm{PC}=$ value of profile curvature, $\mathrm{Fr} \_\mathrm{LULC}=$ value of land use land cover, Fr_NDVI = value of normalized difference vegetation index, Fr_DD = value of drainage density, $\mathrm{Fr} \_\mathrm{RD}=$ value of road density, $\mathrm{Fr} \_\mathrm{Ge}=$ value of geology and $\mathrm{Fr} \_\mathrm{Ra}=$ value of rainfall.

\subsection{Validation method}

In landslide susceptibility studies, the work should not only produce LSM, but also validate the prepared LSM for proper implementation and planning. The validity, 
Fig. 9 Drainage density map

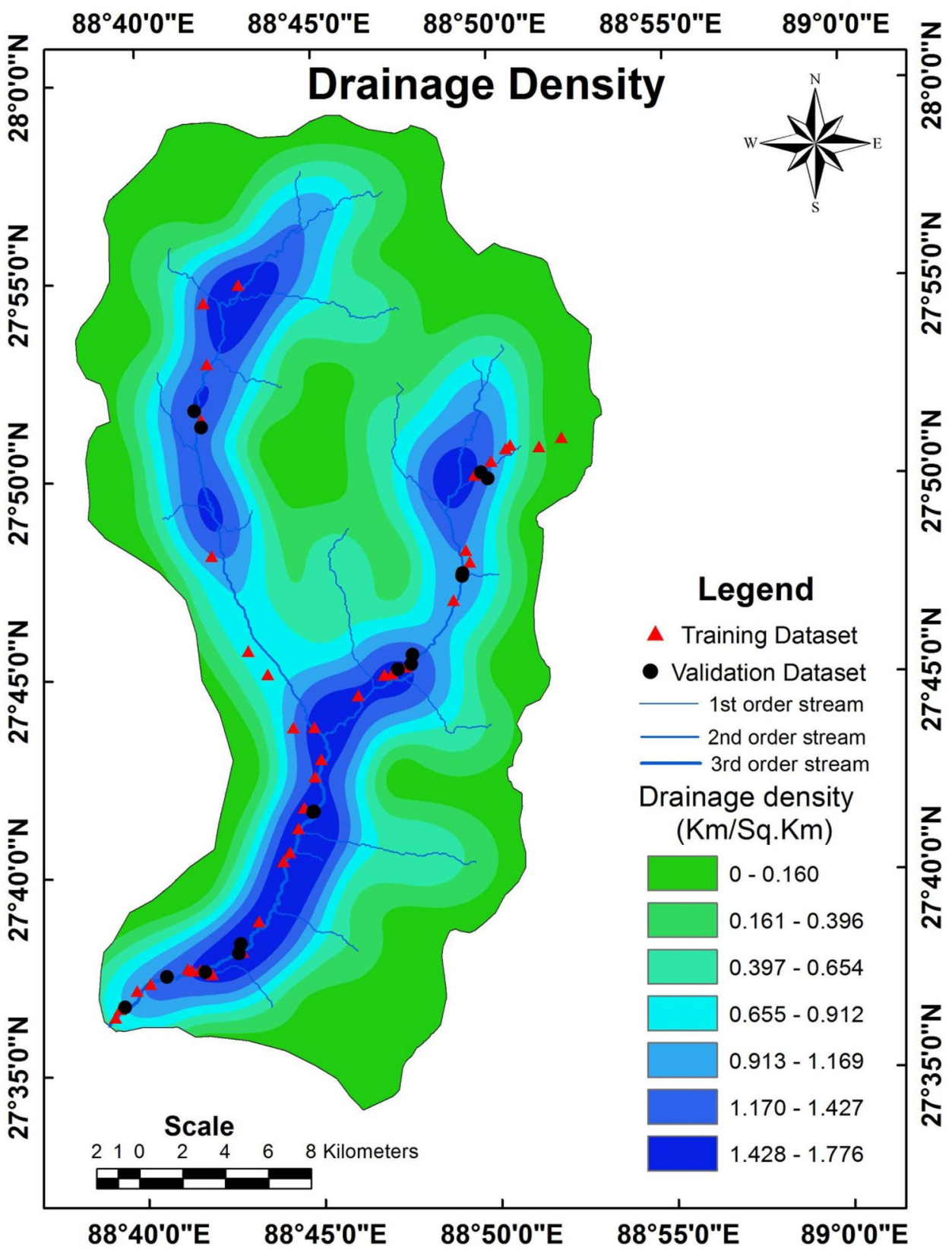

accuracy and quality of susceptibility model were examined by different authors using different methods such as area under the curve (AUC), receiver operating characteristic (ROC) curve, success rate curve and prediction rate curve $[8,28,49]$. Accuracy assessment was prescribed by comparing the ground truths landslides and the landslide susceptibility map. ROC curve is a graphical presentation that shows the performance of model and map. It is dependent on true positive rate (sensitivity) and false positive rate (1-specificity), and the true positive rates ( $Y$-axis) are imprinted against the false positive rates ( $X$ axis) with the proper cutoff value of accuracy assessment (Fig. 18). The validation datasets (16th landslide points) have been used to know the prediction rate, and the training datasets (38th landslide points) have been used to know the success rate. The ROC value ranges from 0.5 to 1.0 ; the ROC value near 0.5 [49] means less accuracy and near 1.0 indicates better accuracy. 
Fig. 10 Road density map

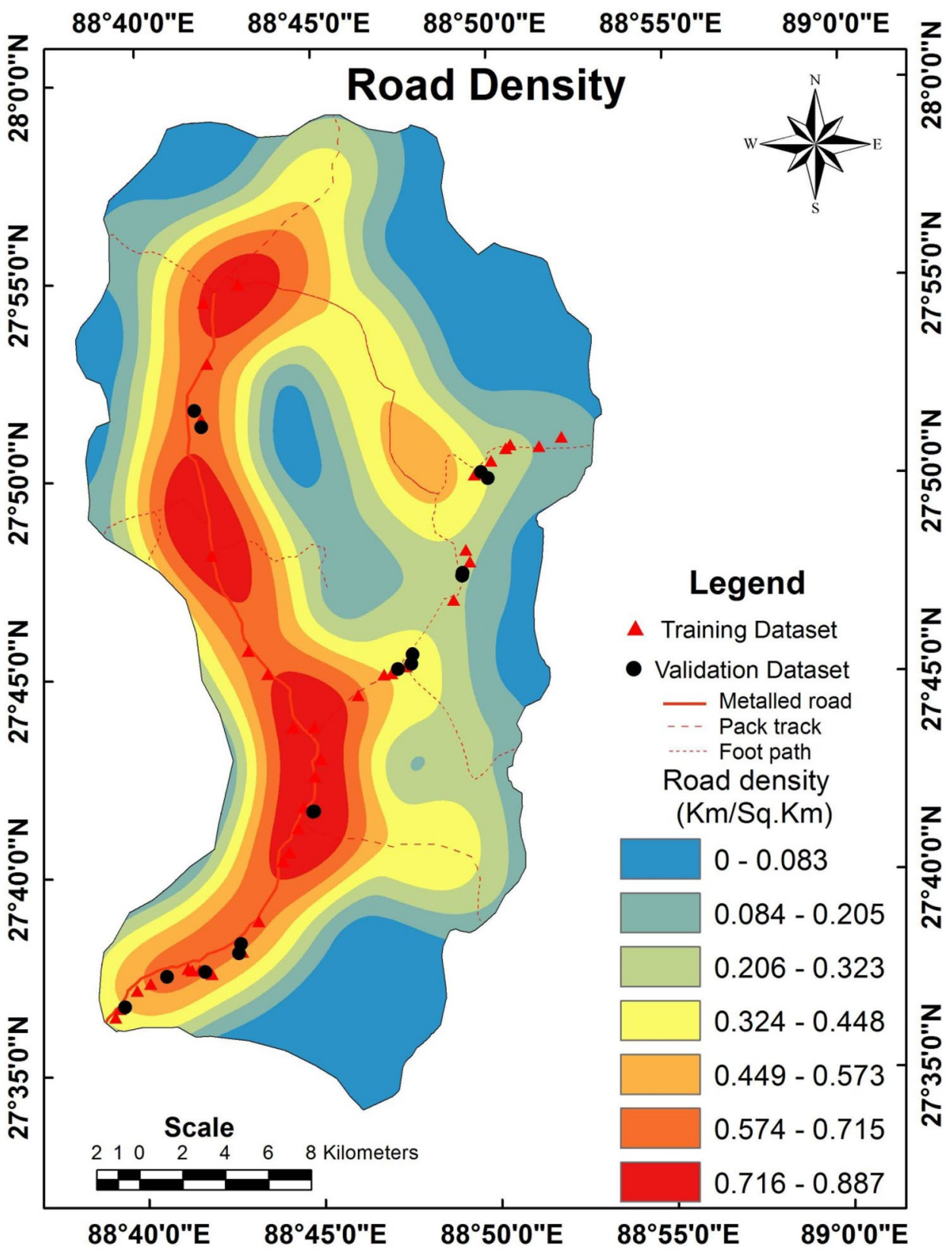

\section{Results}

Landslide is caused by different factors. The ten causative factors are used as input data for the landslide susceptibility method. We have used frequency ratio method to know the determinant factor for landslide occurrences and the spatial distribution of landslide. It can represent the relationship between landslide occurrences and factors explicitly. We have applied frequency ratio method for landslide susceptibility mapping in the study. This method has been validated by applying receiving operating characteristics (ROC) curve.

\subsection{Landslide occurrences for individual factors}

Each and every individual factor has been discussed to highlight the active classes within and between the factors on the basis of value of frequency (Table 3 ). In the slope angle map, slope class $35.488^{\circ}-43.580^{\circ}$ has the highest frequency ratio (FR) value $(1.523)$ and $52.923^{\circ}-79.379^{\circ}$ 
Table 2 Geological formation

\begin{tabular}{|c|c|c|c|c|}
\hline Geological time & Name of the group & Name of the formation & Name of the rocks & $\begin{array}{l}\text { Symbol of } \\
\text { geological } \\
\text { units }\end{array}$ \\
\hline Cenozoic & & Intrusive & $\begin{array}{l}\text { Tourmaline/biotite leuco granite, Schrall rock/ } \\
\text { pegmatite, aplite (undifferentiated) }\end{array}$ & $\mathrm{yCz}$ \\
\hline \multirow[t]{3}{*}{ Proterozoic (undifferentiated) } & & Basic intrusive & Amphibole schist/amphibolites & Pta \\
\hline & $\begin{array}{l}\text { Central Crystalline } \\
\text { Gneissic Complex } \\
\text { (CCGC) }\end{array}$ & $\begin{array}{l}\text { Kanchenjunga Gneiss/ } \\
\text { Darjeeling Gneiss } \\
\text { (undifferentiated) }\end{array}$ & $\begin{array}{l}\text { 1. Banded/streaky migmatite, augen-bearing } \\
\text { (gamet) biotite gneiss with/without kynite, } \\
\text { sillimanite with paleosomes of staurolite, } \\
\text { kyanite, mica schist. } \\
\text { 2. Biotite gneiss } \\
\text { 3. Sillimanite granite gneiss }\end{array}$ & Ptck \\
\hline & & Chungthang Formation & $\begin{array}{l}\text { 1. Quartzite } \\
\text { 2. Gamet kyanite sillimanite biotite schist/ } \\
\text { Gamatiferous mica schist } \\
\text { 3. Calc-granulite (locally gneissic) with interca- } \\
\text { lations of quartzite } \\
\text { 4. Graphite schist }\end{array}$ & Ptcc \\
\hline
\end{tabular}

the lowest FR value (0.0). The relationship between slope angle and landslide occurrence is being positive. South, southeast and east direction slope aspect classes show the high occurrence of landslide. Southeast slope direction shows the highest value (2.699), whereas northwest direction and flat land indicate the lowest frequency ratio value $(0.323,0.0)$. The frequency value shows that elevation class $1583.000-3124.070 \mathrm{~m}$ is high frequency ratio value (7.566) and above $4604.283 \mathrm{~m}$ is low (0.0) frequency ratio value. In the present study, profile curvature classes of high concave $(0.443-1.762,4.138-33.960)$ slope have the highest frequency ratio values of 1.636 and 1.963 , respectively. The lowest FR (0.0) value shows the low convex slope $(-33.337$ to -4.307$)$. In the land use land cover class, high (3.181) FR value is found in barren land followed by grass land, dense forest and snowmelt land. The low FR value $(0.00)$ is found within snow cover area. NDVI class $0.287-0.463$ indicates high (2.618) and classes -0.497 to -0.148 and -0.147 to 0.001 indicate low $(0.00)$ frequency ratio value. It means there is a negative relationship between NDVI (vegetation) and landslide occurrence. Drainage density is the most effective factor among the ten factors in this study. Drainage density class $1.428-1.776 \mathrm{~km} / \mathrm{sq} . \mathrm{km}$ indicates the high frequency ratio value (7.331), followed by $0.913-1.169 \mathrm{~km} / \mathrm{sq} . \mathrm{km}(1.887)$ and $1.170-1.427 \mathrm{~km} / \mathrm{sq}$. $\mathrm{km}$ (1.766), respectively. $0.397-0.654 \mathrm{~km} / \mathrm{sq} . \mathrm{km}$ densities show the lowest frequency ratio value $(0.0)$. Road density class $0.716-0.887 \mathrm{~km} / \mathrm{sq} . \mathrm{km}$ area from the road shows the highest FR value (3.837), followed by $0.574-0.715 \mathrm{~km} / \mathrm{sq}$. $\mathrm{km}$ (2.412). Rest of the road density classes indicates the low FR value. Among the geological rocks bed types, the Chungthang Formation under the rocks of quartzite, biotite schist, mica schist, graphite schist and calc-granulite and intrusive rocks of Cenozoic era has the high frequency ratio value (3.180 and 4.540) and also the high probability of landslide occurrence. Basic intrusive (amphibole schist or amphibolites) has the lowest frequency ratio value $(0.00)$ as well as low probability of landslide occurrence. The rainfall class $2465.593-2844.359 \mathrm{~mm}$ has the high FR value (3.932). The rainfall classes $367.813-707.731 \mathrm{~mm}$ and $707.732-1028.225 \mathrm{~mm}$ have the low FR value (0.0).

\subsection{Landslide susceptibility map (LSM)}

The landslide vulnerability map is classified into seven classes manually based on the probability of landslide occurrences on the field (Fig. 14). In the landslide susceptibility map, 22.672-28.872 pixels showed the very high susceptibility zone (0.591\% area), 20.534 to 22.671 pixels high susceptibility zone (1.867\% area), $17.471-20.533$ pixels moderately high susceptibility zone $(5.172 \%$ area), $12.285-17.470$ pixels moderate $(19.682 \%$ area), $8.623-12.284$ pixels moderately low ( $25.685 \%$ area), $4.834-8.622$ pixels low ( $29.816 \%$ area) and $0.754-4.833$ pixels very low ( $17.187 \%$ area). The roadside and riverside belong to very high to moderate zone ( $27.852 \%$ area), and rest of the part belong to low to very low susceptibility zone of the basin (Table 4). So, landslide possibilities are very high along to the river banks and roadside entire the river basin (Figs. 14, 15). 
Fig. 11 Geology map

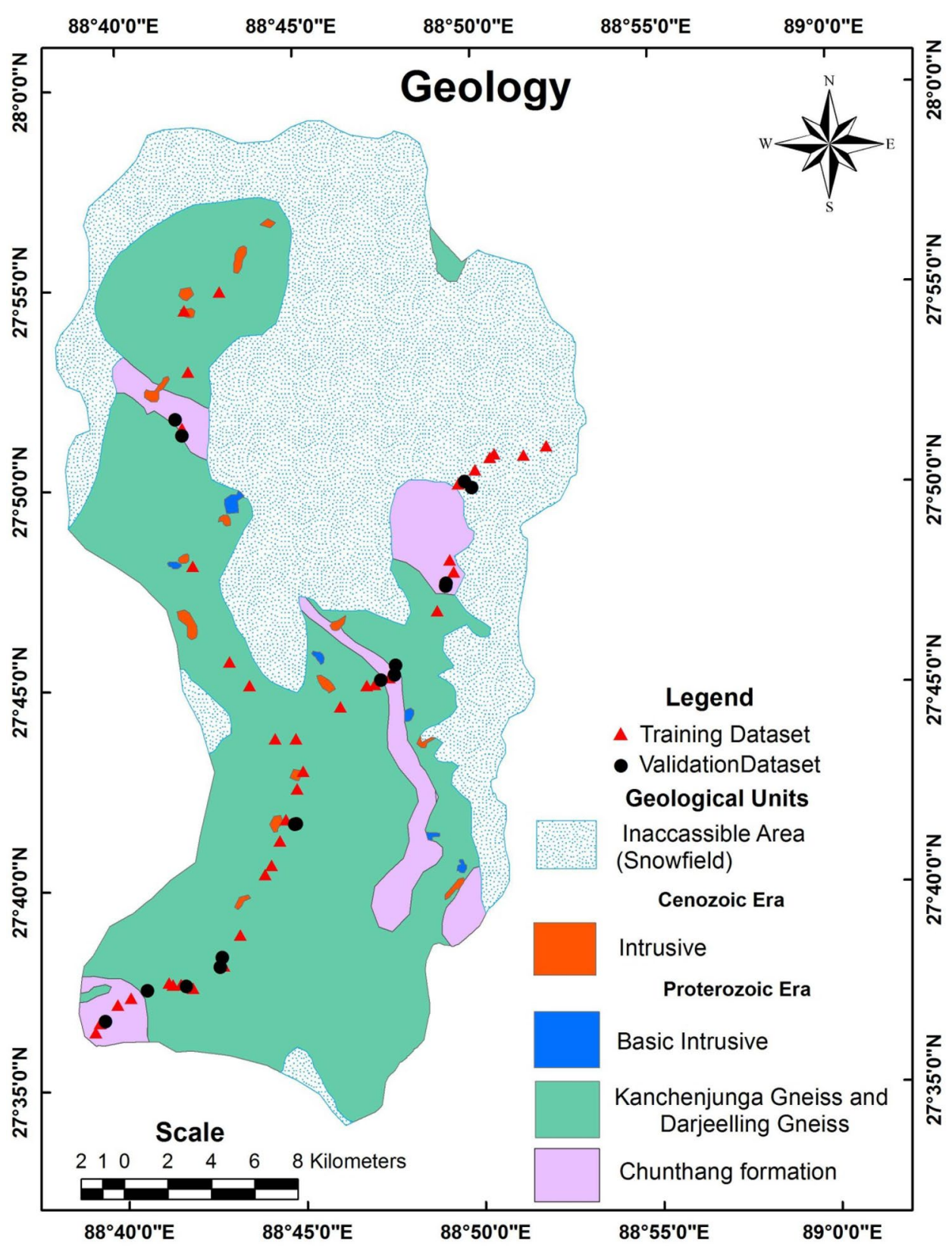

\section{Discussion}

All the factors have the contribution on landslide occurrences in which some are major and minor contributory factors. To know the dominant factors among all, the values of FR for a factor have been summed up and a bar diagram has been plotted (Table 3, Fig. 16). Considering the summed value of FR, Fig. 16 shows that the highest frequency ratio value of all classes is obtained from elevation class (16.634\%), then followed by drainage density (13.864\%), and they are highly dominant factors. Geology $(10.491 \%)$, road density $(10.248 \%)$, NDVI $(10.100 \%)$ and LULC (9.070\%) were also found to be moderately effective factors. The other layers such as slope aspect $(8.898 \%)$, rainfall $(8.720 \%)$, profile curvature $(7.111 \%)$ and slope angle (6.864\%) were observed as less influential factors (Table 3 ). The most of the landslide occurred in low and medium elevation and these areas are highly 
Fig. 12 Rainfall map

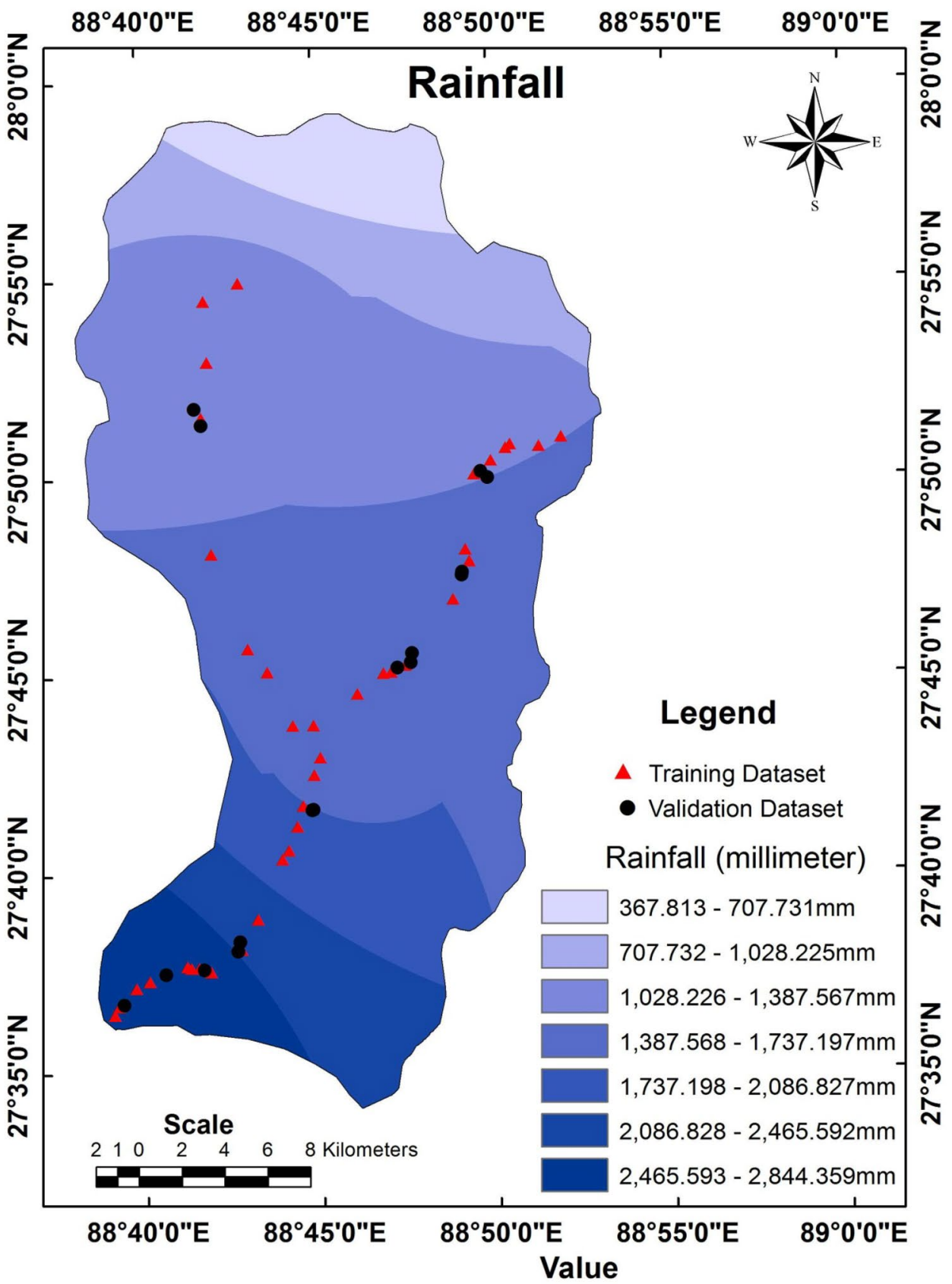

landslide-prone area (Fig. 5) than that in the very high elevation because very high and high elevation is covered by snow throughout the year and man interferences have been observed comparatively in low elevation in Lachung River basin. Downcutting erosion of a river made cliff along the two banks of river which caused landslide; from Lachung to Yumthang many riverside landslide can be found (Fig. 15). It is highly increased in rainy season. It has been observed during the field that the saturated area and the area which is a confluence of two rivers belonged to the landslides. Lachung basins are formed by undifferentiated igneous and metamorphic rocks. Undifferentiated geological structure (Table 2 ) has high probability of weathering and erosion because this geological formation is stiff but many types of rocks are formed together. Near the road is a very landslide-prone area due to the following 
Fig. 13 Rainfall dispersion diagram
Rainfall Dispersion Diagram (1901 - 2018)

Station: North Sikkim

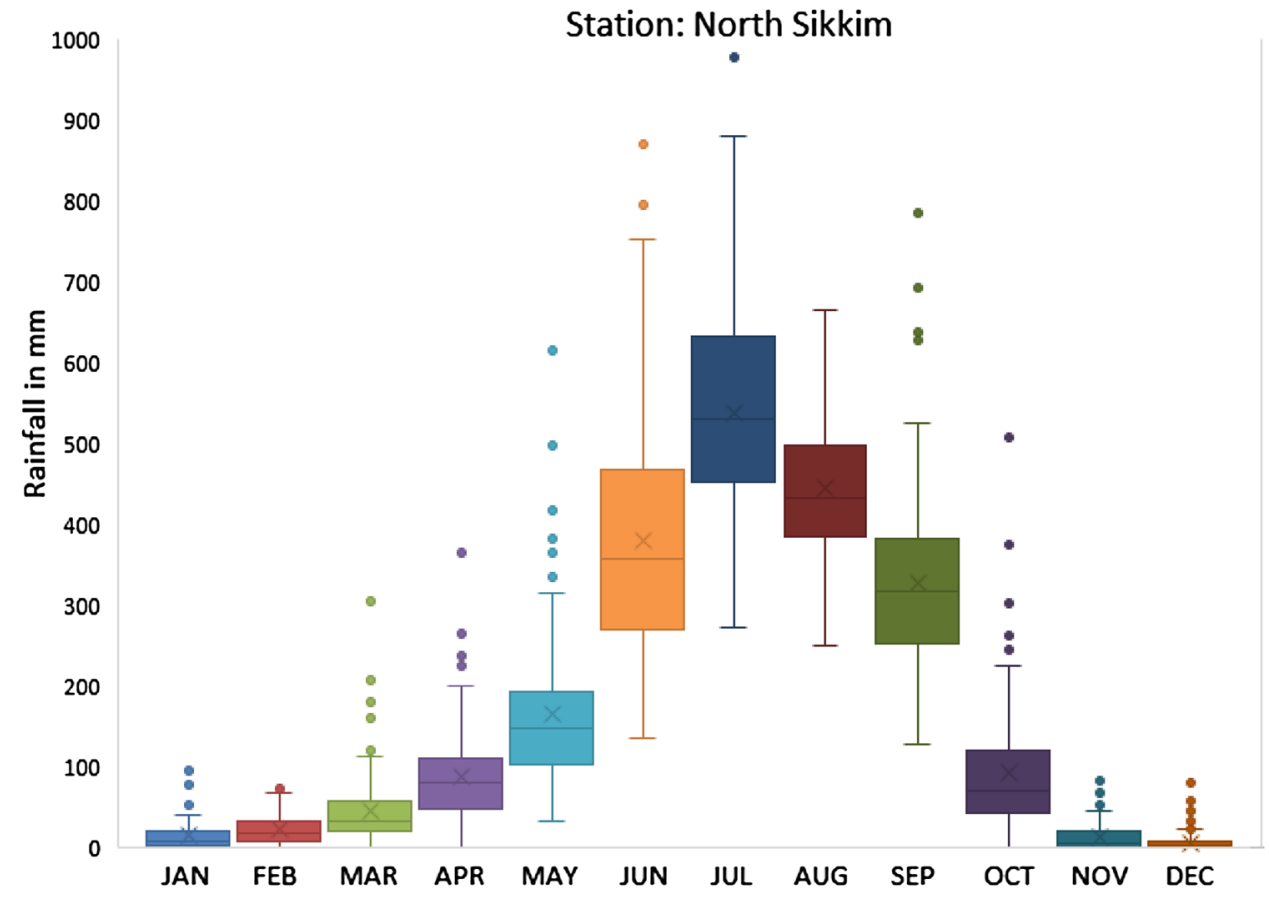

causes. Hill broke down by the road constructions along the steep slope and the vehicle's speed and weight has created a vibration close to the road. Many landslide occurrences have been found along the road of Lachung to Chungthang (Fig. 15). Few landslides have been found on high vegetated area, so there are negative relationships between the vegetation and landslide occurrence. Under the snow line area is found more landslide occurrence area because this area has touched with molten ice in all the time. So snow-covered land is facing minimum landslide and barren and snowmelt areas have maximum. The sun-facing slopes such as south, southeast and southwest slopes have more sunbeam and rainfall in this study area, so activeness of landslide incidence is found in sun-facing slopes. The high rainfall is caused for triggering unexpected landslide. So, rainfall is the denominator of landslide; September 14 and 15, 2018, rain-induced landslides hit the Lachung area. High convex and concave slope in any height of a hill has a possibility of landslide with the contact of water. In this study, medium to high slope gradient $\left(11^{\circ}-43^{\circ}\right)$ is one of the main causes of landslide which means with increasing rate of slope angle, landslide occurrences also increased up to $43^{\circ}$ slope.

\subsection{Landslide density analysis}

The ratio between the percentage of existing landslide area and the area of each landslide susceptibility zone is called landslide density [25]. The study has applied the frequency ratio method that determines zone-wise landslide density; high (44.550) landslide density is found in the very high landslide susceptibility zone and low $(0.00)$ density is found in low and very low landslide susceptibility zones (Table 4). The highest landslide density is found in the very high landslide susceptibility zone, which means frequency ratio model has a significant role in landslide susceptibility mapping. A line graph of landslide density against landslide susceptibility zone is shown in Fig. 17.

\section{LSM validation through ROC curve}

In this study, ROC curve for landslide susceptibility map is prepared by applying statistical software with the help of success and prediction rate. Success rate result 
Table 3 Results of the frequency ratio analysis (FR) of each factor

\begin{tabular}{|c|c|c|c|c|c|c|c|}
\hline Conditioning factor & Classes & $\begin{array}{l}\text { Pixels } \\
\text { number in } \\
\text { domain }\end{array}$ & $\begin{array}{l}\text { Pixels number } \\
\text { in domain (in } \\
\% \text { ) }\end{array}$ & $\begin{array}{l}\text { Number } \\
\text { of land- } \\
\text { slide }\end{array}$ & $\begin{array}{l}\text { Number of } \\
\text { landslide (in } \\
\%)\end{array}$ & $\begin{array}{l}\text { Frequency } \\
\text { ratio (FR) } \\
\text { value }\end{array}$ & $\begin{array}{l}\text { Sum of FR value } \\
\text { of each factor }\end{array}$ \\
\hline \multirow[t]{7}{*}{ Slope angle $\left(^{\circ}\right)$} & $0-11.828$ & 111,495 & 12.778 & 3 & 7.895 & 0.618 & $6.129(6.864 \%)$ \\
\hline & 11.829-20.233 & 160,845 & 18.434 & 10 & 26.316 & 1.428 & \\
\hline & 20.234-28.016 & 169,870 & 19.469 & 6 & 15.789 & 0.811 & \\
\hline & $28.017-35.487$ & 160,380 & 18.381 & 7 & 18.421 & 1.002 & \\
\hline & $35.488-43.580$ & 135,651 & 15.547 & 9 & 23.684 & 1.523 & \\
\hline & $43.581-52.919$ & 92,248 & 10.572 & 3 & 7.895 & 0.747 & \\
\hline & $52.923-79.379$ & 42,045 & 4.819 & 0 & 0.000 & 0.000 & \\
\hline \multirow[t]{9}{*}{ Slope Aspect } & Flat $(-1)$ & 40 & 0.005 & 0 & 0.000 & 0.000 & $7.946(8.898 \%)$ \\
\hline & $\begin{array}{l}\text { North (0-22.5; } \\
337.5-360)\end{array}$ & 80,850 & 9.266 & 2 & 5.263 & 0.568 & \\
\hline & Northeast (22.5-67.5) & 85,088 & 9.752 & 3 & 7.895 & 0.810 & \\
\hline & East (67.5-112.5) & 103,561 & 11.869 & 5 & 13.158 & 1.109 & \\
\hline & $\begin{array}{l}\text { Southeast (112.5- } \\
\text { 157.5) }\end{array}$ & 110,608 & 12.677 & 13 & 34.211 & 2.699 & \\
\hline & South (157.5-202.5) & 98,161 & 11.250 & 9 & 23.684 & 2.105 & \\
\hline & $\begin{array}{l}\text { Southwest (202.5- } \\
\text { 247.5) }\end{array}$ & 137,953 & 15.811 & 2 & 5.263 & 0.333 & \\
\hline & West (247.5-292.5) & 142,112 & 16.287 & 2 & 5.263 & 0.323 & \\
\hline & $\begin{array}{l}\text { Northwest (292.5- } \\
\text { 337.5) }\end{array}$ & 114,201 & 13.088 & 2 & 5.263 & 0.402 & \\
\hline \multirow[t]{7}{*}{ Elevation (m) } & $1583.000-2775.070$ & 36,419 & 4.174 & 12 & 31.579 & 7.566 & $13.068(16.634 \%)$ \\
\hline & $2775.071-3494.423$ & 74,700 & 8.561 & 11 & 28.947 & 3.381 & \\
\hline & $3494.424-4090.458$ & 112,954 & 12.946 & 4 & 10.526 & 0.813 & \\
\hline & $4090.459-4604.282$ & 153,436 & 17.585 & 3 & 7.895 & 0.449 & \\
\hline & $4604.283-5056.447$ & 213,864 & 24.511 & 8 & 21.053 & 0.859 & \\
\hline & $5056.448-5590.823$ & 234,107 & 26.831 & 0 & 0.000 & 0.000 & \\
\hline & $5590.824-6824.000$ & 47,054 & 5.393 & 0 & 0.000 & 0.000 & \\
\hline \multirow[t]{7}{*}{ Profile curvature } & -33.337 to -4.307 & 10,862 & 1.245 & 0 & 0.000 & 0.000 & $6.350(7.111 \%)$ \\
\hline & -4.306 to -1.932 & 68,006 & 7.794 & 1 & 2.632 & 0.338 & \\
\hline & -1.931 to -0.612 & 184,044 & 21.093 & 5 & 13.158 & 0.624 & \\
\hline & -0.611 to 0.442 & 291,878 & 33.452 & 12 & 31.579 & 0.944 & \\
\hline & 0.443 to 1.762 & 224,611 & 25.742 & 16 & 42.105 & 1.636 & \\
\hline & 1.763 to 4.137 & 81,436 & 9.333 & 3 & 7.895 & 0.846 & \\
\hline & 4.138 to 33.960 & 11,697 & 1.341 & 1 & 2.632 & 1.963 & \\
\hline \multirow{5}{*}{$\begin{array}{l}\text { Land use and land } \\
\text { cover }\end{array}$} & Dense forest & 186,693 & 21.397 & 11 & 28.947 & 1.353 & 8.099 (9.070\%) \\
\hline & Grass land & 58,690 & 6.726 & 6 & 15.789 & 2.347 & \\
\hline & Barren land & 79,392 & 9.099 & 11 & 28.947 & 3.181 & \\
\hline & Snowfield & 359,211 & 41.169 & 0 & 0.000 & 0.000 & \\
\hline & Snowmelt area & 188,548 & 21.609 & 10 & 26.316 & 1.218 & \\
\hline \multirow{7}{*}{$\begin{array}{l}\text { Normalized differ- } \\
\text { ences vegetation } \\
\text { index (NDVI) }\end{array}$} & -0.497 to -0.148 & 1653 & 0.189 & 0 & 0.000 & 0.000 & 9.019 (10.100\%) \\
\hline & -0.147 to 0.001 & 375,757 & 43.065 & 0 & 0.000 & 0.000 & \\
\hline & 0.002 to 0.130 & 109,082 & 12.502 & 10 & 26.316 & 2.105 & \\
\hline & 0.131 to 0.286 & 88,549 & 10.148 & 5 & 13.158 & 1.297 & \\
\hline & 0.287 to 0.463 & 78,941 & 9.047 & 9 & 23.684 & 2.618 & \\
\hline & 0.464 to 0.635 & 84,576 & 9.693 & 6 & 15.789 & 1.629 & \\
\hline & 0.636 to 0.872 & 133,976 & 15.355 & 8 & 21.053 & 1.371 & \\
\hline
\end{tabular}


Table 3 (continued)

\begin{tabular}{|c|c|c|c|c|c|c|c|}
\hline Conditioning factor & Classes & $\begin{array}{l}\text { Pixels } \\
\text { number in } \\
\text { domain }\end{array}$ & $\begin{array}{l}\text { Pixels number } \\
\text { in domain (in } \\
\% \text { ) }\end{array}$ & $\begin{array}{l}\text { Number } \\
\text { of land- } \\
\text { slide }\end{array}$ & $\begin{array}{l}\text { Number of } \\
\text { landslide (in } \\
\%)\end{array}$ & $\begin{array}{l}\text { Frequency } \\
\text { ratio }(F R) \\
\text { value }\end{array}$ & $\begin{array}{l}\text { Sum of FR value } \\
\text { of each factor }\end{array}$ \\
\hline \multirow{7}{*}{$\begin{array}{l}\text { Drainage density (km/ } \\
\text { sq. km) }\end{array}$} & $0.000-0.160$ & 256,591 & 29.408 & 1 & 2.632 & 0.089 & \multirow[t]{7}{*}{$12.380(13.864 \%)$} \\
\hline & $0.161-0.396$ & 161,847 & 18.549 & 1 & 2.632 & 0.142 & \\
\hline & $0.397-0.654$ & 135,950 & 15.581 & 0 & 0.000 & 0.000 & \\
\hline & $0.655-0.912$ & 98,573 & 11.297 & 5 & 13.158 & 1.165 & \\
\hline & $0.913-1.169$ & 85,190 & 9.764 & 7 & 18.421 & 1.887 & \\
\hline & $1.170-1.427$ & 78,003 & 8.940 & 6 & 15.789 & 1.766 & \\
\hline & $1.428-1.776$ & 56,380 & 6.462 & 18 & 47.368 & 7.331 & \\
\hline \multirow{7}{*}{$\begin{array}{l}\text { Road density (km/sq. } \\
\mathrm{km} \text { ) }\end{array}$} & $0.000-0.083$ & 173,093 & 19.838 & 0 & 0.000 & 0.000 & \multirow[t]{7}{*}{$9.151(10.248 \%)$} \\
\hline & $0.084-0.205$ & 146,951 & 16.842 & 2 & 5.263 & 0.313 & \\
\hline & $0.206-0.323$ & 153,272 & 17.566 & 6 & 15.789 & 0.899 & \\
\hline & $0.324-0.448$ & 146,061 & 16.740 & 6 & 15.789 & 0.943 & \\
\hline & $0.449-0.573$ & 92,145 & 10.561 & 3 & 7.895 & 0.748 & \\
\hline & $0.574-0.715$ & 95,181 & 10.909 & 10 & 26.316 & 2.412 & \\
\hline & $0.716-0.887$ & 65,831 & 7.545 & 11 & 28.947 & 3.837 & \\
\hline \multirow[t]{7}{*}{ Rainfall (mm) } & $367.813-707.731$ & 50,020 & 5.733 & 0 & 0.000 & 0.000 & \multirow[t]{7}{*}{7.787 (8.720\%) } \\
\hline & $707.732-1028.225$ & 90,592 & 10.383 & 0 & 0.000 & 0.000 & \\
\hline & 1028.226-1387.567 & 260,677 & 29.876 & 10 & 26.316 & 0.881 & \\
\hline & 1387.568-1737.197 & 273,998 & 31.403 & 14 & 36.842 & 1.173 & \\
\hline & 1737.198-2086.827 & 79,688 & 9.133 & 4 & 10.526 & 1.153 & \\
\hline & 2086.828-2465.592 & 70,846 & 8.120 & 2 & 5.263 & 0.648 & \\
\hline & $2465.593-2844.359$ & 46,713 & 5.354 & 8 & 21.053 & 3.932 & \\
\hline \multirow[t]{5}{*}{ Geology } & $\begin{array}{l}\text { Inaccessible area } \\
\text { (snowfield) }\end{array}$ & 404,425 & 46.351 & 6 & 15.789 & 0.341 & \multirow[t]{5}{*}{9.368 (10.491\%) } \\
\hline & Intrusive & 5058 & 0.580 & 1 & 2.632 & 4.540 & \\
\hline & Basic intrusive & 1630 & 0.187 & 0 & 0.000 & 0.000 & \\
\hline & $\begin{array}{l}\text { Kanchenjunga Gneiss } \\
\text { and Darjeeling } \\
\text { Gneiss }\end{array}$ & 403,650 & 46.262 & 23 & 60.526 & 1.308 & \\
\hline & Chunthang Formation & 57,771 & 6.621 & 8 & 21.053 & 3.180 & \\
\hline
\end{tabular}

was taken from using the $70 \%$ training dataset (38th landslides), and the prediction rate was calculated by using the validating dataset (16th landslides). The AUC of prediction rate and success rate of ROC curve is 0.889 and 0.923 , respectively, for landslide susceptibility map and frequency ratio model (Fig. 18). It means this model is $88.9 \%$ accurate to predict the probability of landslide and the model is $92.3 \%$ success to generate the prediction in the study area.

\section{Conclusion}

Landslide is a significant geo-hazard; it has a detrimental impact on human and civilization. In the study, the frequency ratio was applied to assess landslide susceptibility mapping. The relationship of ten causative factors and landslide occurrences was evaluated by the frequency ratio model. Thus, we have got the dominant factors of landslide in the Lachung River basin. In this susceptibility 
Fig. 14 Landslide susceptibility map

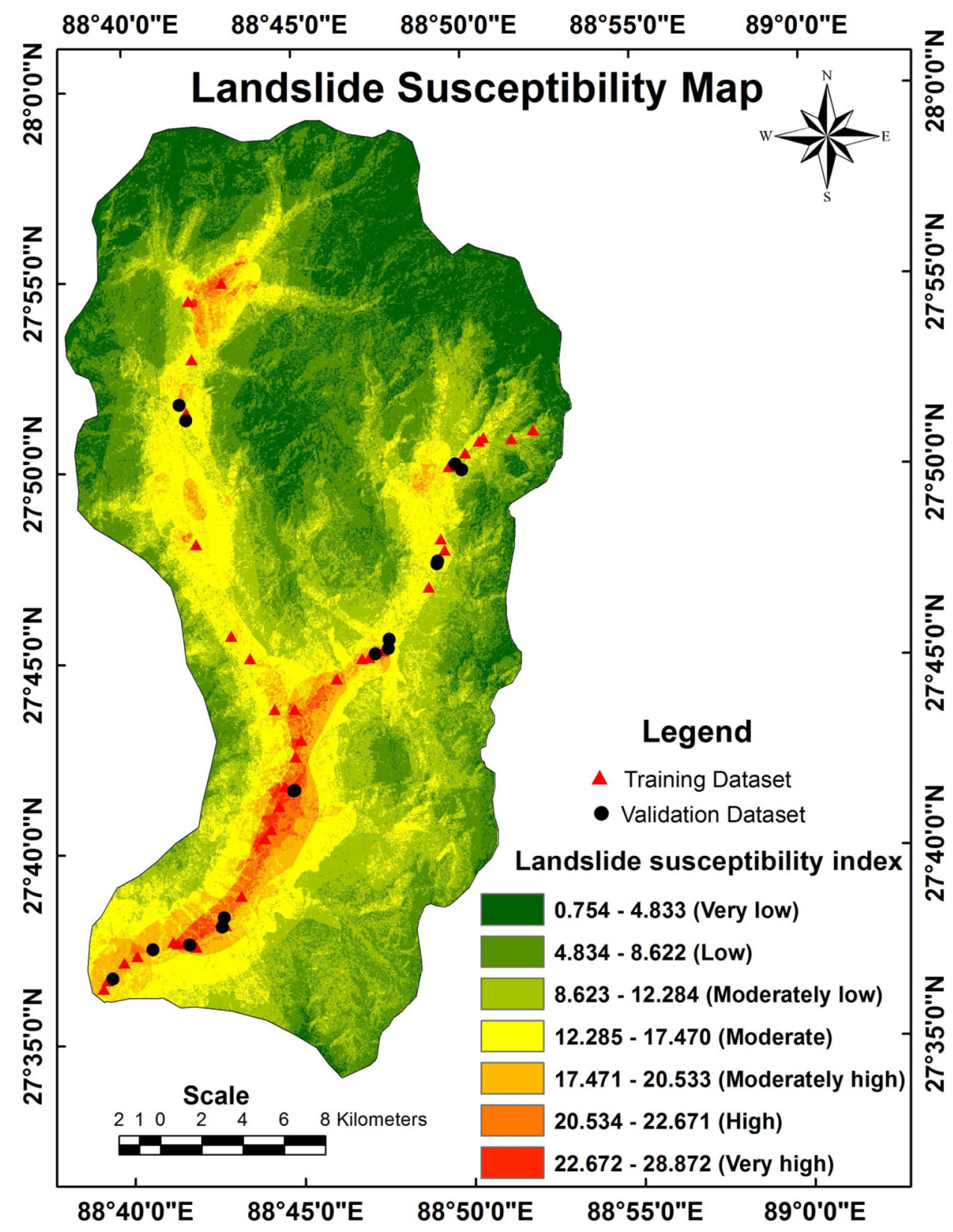

\begin{tabular}{llllll}
\hline $\begin{array}{l}\text { Landslide sus- } \\
\text { ceptibility zone }\end{array}$ & $\begin{array}{l}\text { Area of suscep- } \\
\text { tibility zone (sq. } \\
\mathrm{km})\end{array}$ & $\begin{array}{l}\text { Percentage (\%) of area } \\
\text { of Susceptibility zone }\end{array}$ & $\begin{array}{l}\text { Number of } \\
\text { landslide per } \\
\text { zone }\end{array}$ & $\begin{array}{l}\text { \% of land- } \\
\text { slide per } \\
\text { zone }\end{array}$ & $\begin{array}{l}\text { Density of } \\
\text { landslide }\end{array}$ \\
\hline Very low & 130.708 & 17.187 & 0 & 0.00 & 0.00 \\
Low & 226.757 & 29.816 & 1 & 2.63 & 0.09 \\
Moderately low & 195.335 & 25.685 & 3 & 7.89 & 0.31 \\
Moderate & 149.679 & 19.682 & 11 & 28.95 & 1.47 \\
Moderately high & 39.337 & 5.172 & 7 & 18.42 & 3.56 \\
High & 14.199 & 1.867 & 6 & 15.79 & 8.46 \\
Very high & 4.492 & 0.591 & 10 & 26.32 & 44.55 \\
\hline
\end{tabular}

Table 4 Landslide zone area and landslide density of the study area 

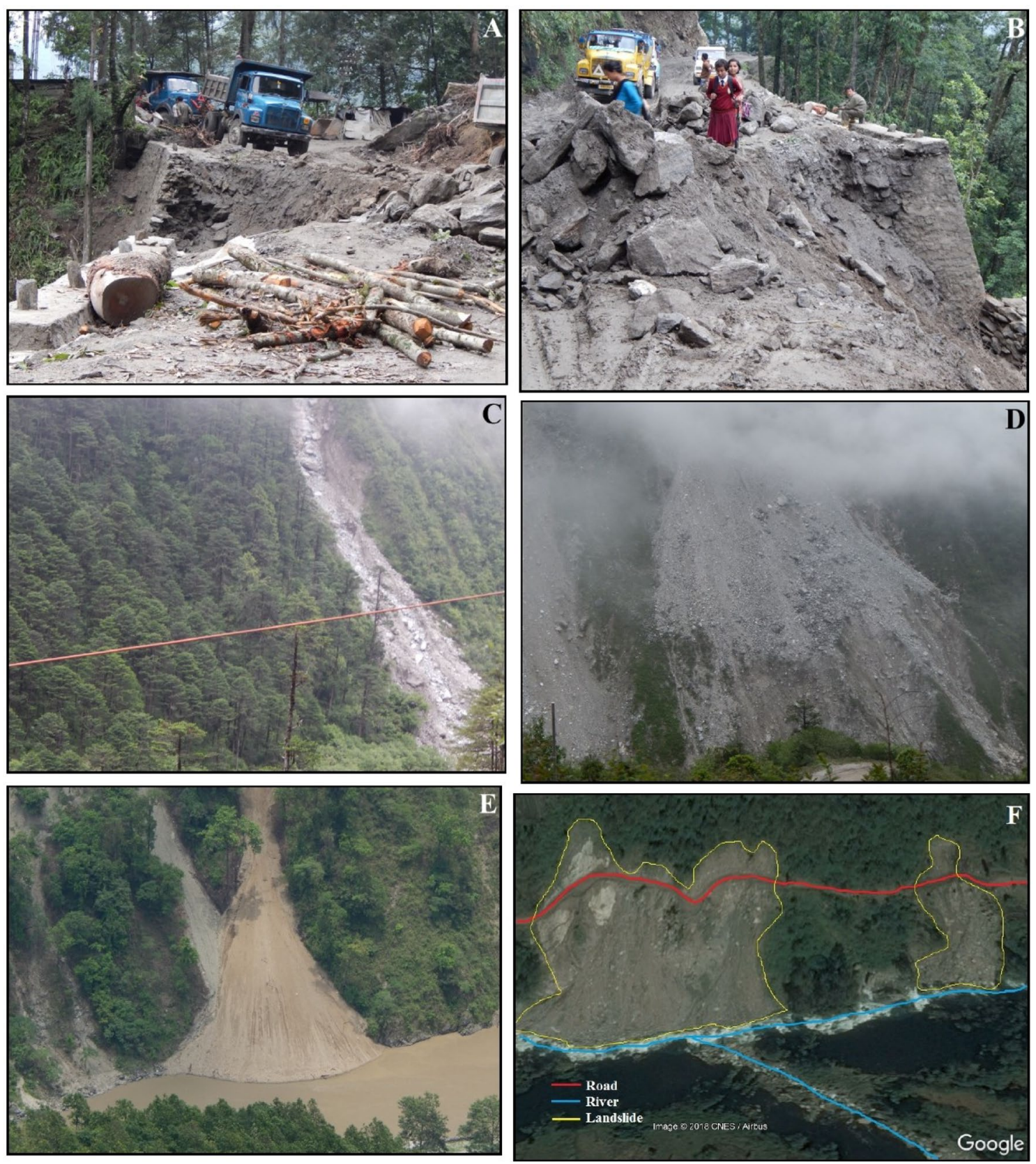

Fig. 15 Field photograph showing different types of landslide; a landslide along the Lachung to Yumthang road near snow point, b roadside landslide along the Lachung to Chungthang road near

bung, Lachung, e landslide in left side of Lachung River near hot water spring, $\mathbf{f}$ landslide along the Chungthang to Lachung road and Lachung River near Khedum 


\section{Factors of Landslide}

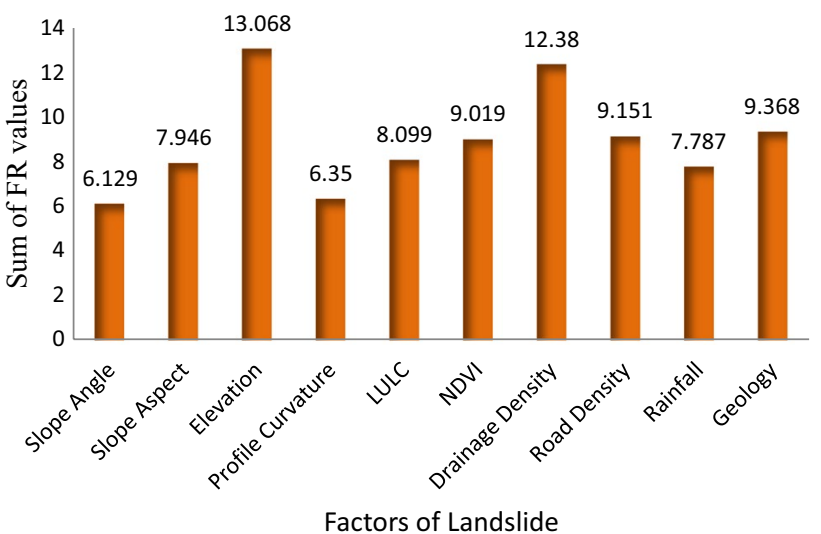

Fig. 16 Dominant factor of landslide

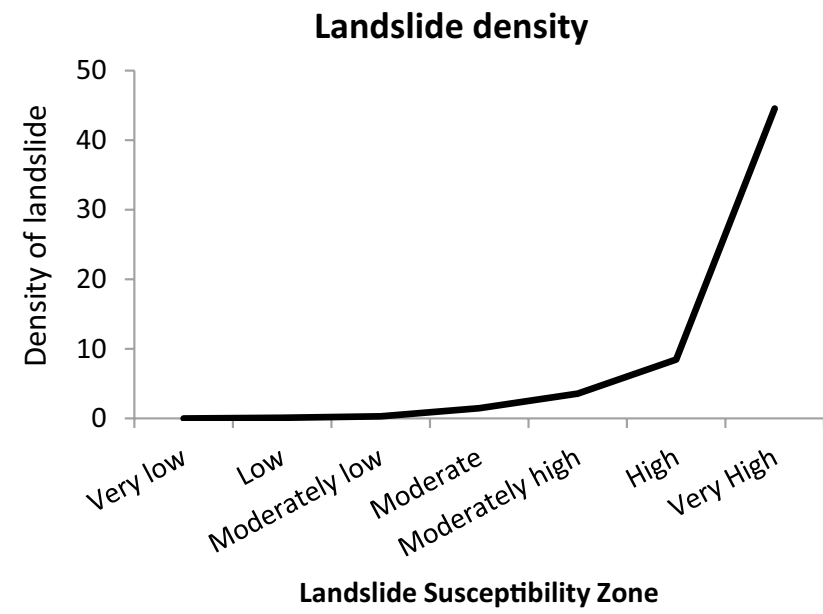

Fig. 17 Landslide density

assessment, we have got seven vulnerable zones, and they are very low, low, moderately low, moderate, moderately high, high and very high. The landslide susceptibility map on the Lachung River basin helps to local planner, engineering works, regional development, tourism industry and tourists because we know which place is landslide vulnerable area. The map has been validated by success rate $(92.3 \%)$ and prediction rate $(88.9 \%)$ of AUC curves. Suitable remedies may consider for very susceptibility landside. These remedies improve surface drainage by the process of shifting small channel from the landslidetriggering area, and sediment should be dredged from the drainage to avoid landslide. The concrete walls should be constructed beside the roadside and the riverside in landslide-prone area. Afforestation should be needed along the landslide-triggering areas.

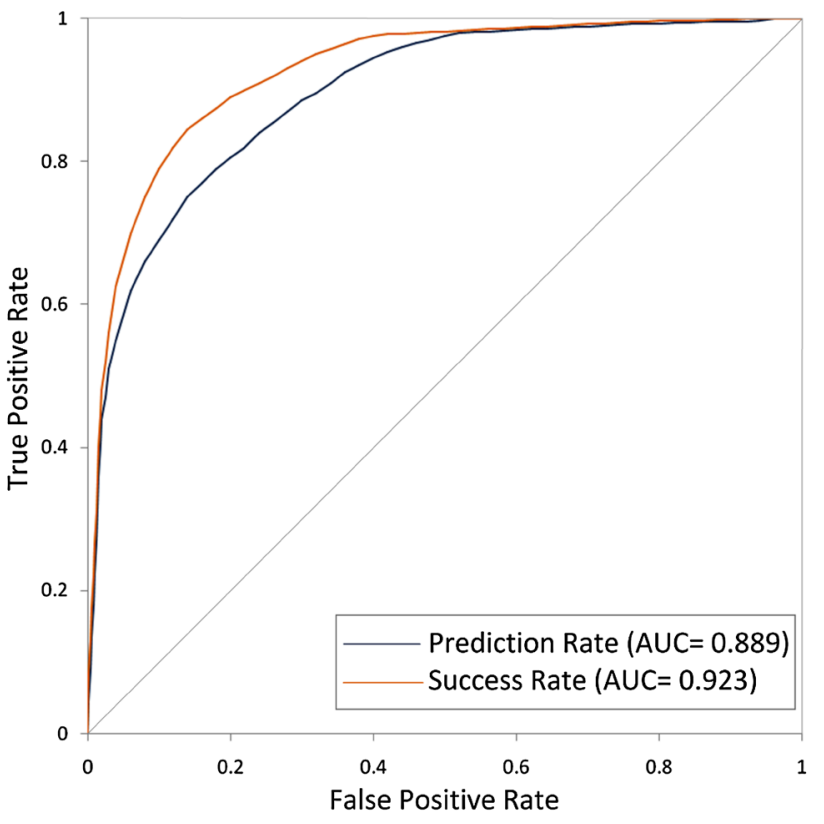

Fig. 18 Receiver operating characteristic $(\mathrm{ROC})$ curve

Acknowledgements We are grateful to Clifford Chuwah, Section Editor, SN Applied Sciences Journal and anonymous reviewers for their valuable suggestions in regard to the improvement in this research article. We are also grateful to State Environment of Sikkim, Government of Sikkim, India, for providing landslide-related data and to U.S. Geological survey, Department of Space and ESA for providing remotely sensed data. We sincerely thank National Atlas and Thematic Mapping Organization, Kolkata, West Bengal, for providing different thematic maps. We are also obliged Mr. Suman Subba and Mr. Anand Chhetri to provide the support during the field visit.

\section{Compliance with ethical standards}

Conflict of interest The authors state that there is no conflict of interest.

\section{References}

1. Chorley RJ, Schumm SA, Sugden DE (1985) Geomorphology. Methuen, London

2. Mandal S, Maiti R (2015) Impact assessment of hydrologic attributes and slope instability. In: Semi-quantitative approaches for landslide assessment and prediction. Springer, Singapore, pp. 95-121. https://doi.org/10.1007/978-981-287-146-6_3

3. Guha-Sapir D, Hoyois P, Wallemacq P, Below R (2017) Annual disaster statistical review 2016: the numbers and trends. http:// emdat.be/sites/default/files/adsr_2016.pdf. Accessed 5 June 2018

4. Mandal B, Mandal S (2018) Analytical hierarchy process (AHP) based landslide susceptibility mapping of Lish river basin of eastern Darjeeling Himalaya, India. Adv Space Res 62(11):3114-3132 
5. Varnes DJ (1984) Landslide hazard zonation: a review of principles and practice. Natural Hazards. UNESCO, Paris

6. Westen CV, Terlien MJT (1996) An approach towards deterministic landslide hazard analysis in GIS. A case study from Manizales (Colombia). Earth Surf Proc Land 21(9):853-868

7. Mousavi SZ, Kavian A, Soleimani K, Mousavi SR, Shirzadi A (2011) GIS-based spatial prediction of landslide susceptibility using logistic regression model. Geomat Nat Hazards Risk 2(1):33-50

8. Basharat M, Shah HR, Hameed N (2016) Landslide susceptibility mapping using GIS and weighted overlay method: a case study from NW Himalayas, Pakistan. Arab J Geosci 9(4):292

9. Keefer DK (1984) Landslides caused by earthquakes. Geol Soc Am Bull 95:406-421

10. Lee $S$ (2005) Application of logistic regression model and its validation for landslide susceptibility mapping using GIS and remote sensing data. Int J Remote Sens 26(7):1477-1491

11. Pourghasemi HR, Mohammady M, Pradhan B (2012) Landslide susceptibility mapping using index of entropy and conditional probability models in GIS: Safarood Basin, Iran. CATENA 97:71-84

12. Aleotti P, Chowdhury R (1999) Landslide hazard assessment: summary review and new perspectives. Bull Eng Geol Env 58(1):21-44

13. Anbalagan R, Singh B (1996) Landslide hazard and risk assessment mapping of mountainous terrains - a case study from Kumaun Himalaya, India. Eng Geol 43(4):237-246

14. Gorsevski PV, Gessler PE, Jankowski P (2003) Integrating a fuzzy k-means classification and a Bayesian approach for spatial prediction of landslide hazard. J Geogr Syst 5(3):223-251

15. Guzzetti F, Carrara A, Cardinali M, Reichenbach P (1999) Landslide hazard evaluation: a review of current techniques and their application in a multi-scale study, Central Italy. Geomorphology 31(1):181-216

16. Varnes DJ (1984) Landslide hazard zonation: a review of principles and practice. Natural hazards. UNESCO, Paris

17. Clerici A, Perego S, Tellini C, Vescovi P (2006) A GIS-based automated procedure for landslide susceptibility mapping by the conditional analysis method: the Baganza valley case study (Italian Northern Apennines). Environ Geol 50(7):941-961

18. Van Westen CJ, Van Asch TW, Soeters R (2006) Landslide hazard and risk zonation-why is it still so difficult? Bull Eng Geol Env 65(2):167-184

19. Kavzoglu T, Sahin EK, Colkesen I (2014) Landslide susceptibility mapping using GIS-based multi-criteria decision analysis, support vector machines, and logistic regression. Landslides 11(3):425-439

20. Lee $S$ (2007) Application and verification of fuzzy algebraic operators to landslide susceptibility mapping. Environ Geol 52:615-623

21. Nsengiyumva JB, Luo G, Nahayo L, Huang X, Cai P (2018) Landslide susceptibility assessment using spatial multi-criteria evaluation model in Rwanda. Int J Environ Res Public Health 15(2):243

22. Pradhan B (2011) Use of GIS-based fuzzy logic relations and its cross application to produce landslide susceptibility maps in three test areas in Malaysia. Environ Earth Sci 63(2):329-349

23. Pardeshi SD, Autade SE, Pardeshi SS (2013) Landslide hazard assessment: recent trends and techniques. SpringerPlus 2(1):523

24. Lee S, Pradhan B (2006) Probabilistic landslide hazards and risk mapping on Penang Island, Malaysia. J Earth Syst Sci 115(6):661-672

25. Mandal SP, Chakrabarty A, Maity P (2018) Comparative evaluation of information value and frequency ratio in landslide susceptibility analysis along national highways of Sikkim Himalaya. Spat Inf Res 26(2):127-141

26. Youssef AM, Hegab MA (2005) Using geographic information systems and statistics for developing a database management system of the flood hazard for Ras Gharib area, Eastern Desert, Egypt. In: The fourth international conference on the geology of Africa, vol 2, pp 1-15

27. Kayastha P, Dhital MR, De Smedt F (2012) Landslide susceptibility mapping using the weight of evidence method in the Tinau watershed, Nepal. Nat Hazards 63(2):479-498

28. Xu C, Xu X, Dai F, Xiao J, Tan X, Yuan R (2012) Landslide hazard mapping using GIS and weight of evidence model in Qingshui river watershed of 2008 Wenchuan earthquake struck region. J Earth Sci 23(1):97-120

29. Du GL, Zhang YS, lqbal J, Yang ZH, Yao X (2017) Landslide susceptibility mapping using an integrated model of information value method and logistic regression in the Bailongjiang watershed, Gansu Province, China. J Mt Sci 14(2):249-268

30. Sarkar S, Roy AK, Martha TR (2013) Landslide susceptibility assessment using information value method in parts of the Darjeeling Himalayas. J Geol Soc India 82(4):351-362

31. Bai SB, Lu P, Wang J (2015) Landslide susceptibility assessment of the Youfang catchment using logistic regression. J Mt Sci 12(4):816-827

32. Wang Q, Li W, Chen W, Bai H (2015) GIS-based assessment of landslide susceptibility using certainty factor and index of entropy models for the Qianyang County of Baoji city, China. J Earth Syst Sci 124(7):1399-1415

33. lovine GG, Greco R, Gariano SL, Pellegrino AD, Terranova OG (2014) Shallow-landslide susceptibility in the Costa Viola mountain ridge (southern Calabria, Italy) with considerations on the role of causal factors. Nat Hazards 73(1):111-136

34. Chauhan S, Sharma M, Arora MK, Gupta NK (2010) Landslide susceptibility zonation through ratings derived from artificial neural network. Int J Appl Earth Obs Geoinf 12(5):340-350

35. Pradhan B, Youssef A, Varathrajoo R (2010) Approaches for delineating landslide hazard areas using different training sites in an advanced artificial neural network model. Geo-spat Inf Sci 13(2):93-102

36. Petschko H, Brenning A, Bell R, Goetz J, Glade T (2014) Assessing the quality of landslide susceptibility maps-case study Lower Austria. Nat Hazards Earth Syst Sci 14(1):95-118

37. Shadman Roodposhti M, Aryal J, Shahabi H, Safarrad T (2016) Fuzzy Shannon entropy: a hybrid GIS-based landslide susceptibility mapping method. Entropy 18(10):343

38. Shirzadi A, Bui DT, Pham BT, Solaimani K, Chapi K, Kavian A et al (2017) Shallow landslide susceptibility assessment using a novel hybrid intelligence approach. Environ Earth Sci 76(2):60

39. Chen W, Xie X, Peng J, Shahabi H, Hong H, Bui DT et al (2018) GISbased landslide susceptibility evaluation using a novel hybrid integration approach of bivariate statistical based random forest method. CATENA 164:135-149

40. Hong H, Liu J, Zhu AX, Shahabi H, Pham BT, Chen W et al (2017) A novel hybrid integration model using support vector machines and random subspace for weather-triggered landslide susceptibility assessment in the Wuning area (China). Environ Earth Sci 76(19):652

41. Mondal S, Mandal S (2018) Data-driven evidential belief function (EBF) model in exploring landslide susceptibility zones for the Darjeeling Himalaya, India. Geocarto Int 1-65 (just-accepted)

42. Chen W, Peng J, Hong H, Shahabi H, Pradhan B, Liu J et al (2018) Landslide susceptibility modelling using GIS-based machine learning techniques for Chongren County, Jiangxi Province, China. Sci Total Environ 626:1121-1135

43. Chen W, Shahabi H, Shirzadi A, Li T, Guo C, Hong H et al (2018) A novel ensemble approach of bivariate statistical-based logistic model tree classifier for landslide susceptibility assessment. Geocarto Int 33(12):1398-1420

44. Shahabi H, Khezri S, Ahmad BB, Hashim M (2014) Landslide susceptibility mapping at central Zab basin, Iran: a comparison 
between analytical hierarchy process, frequency ratio and logistic regression models. CATENA 115:55-70

45. Gunadi DSA, Jaya INS, Tjahjono B (2017) Spatial modeling in landslide susceptibility. Indones J Electr Eng Comput Sci 5(1):139-146

46. Ahmed B, Dewan A (2017) Application of bivariate and multivariate statistical techniques in landslide susceptibility modeling in Chittagong city corporation, Bangladesh. Remote Sens 9(4):304

47. Anbalagan R, Kumar R, Lakshmanan K, Parida S, Neethu S (2015) Landslide hazard zonation mapping using frequency ratio and fuzzy logic approach, a case study of Lachung Valley, Sikkim. Geoenviron Disasters 2(1):6

48. Saha AK, Gupta RP, Arora MK (2002) GIS-based landslide hazard zonation in the Bhagirathi (Ganga) valley, Himalayas. Int J Remote Sens 23(2):357-369

49. Saha AK, Gupta RP, Sarkar I, Arora MK, Csaplovics E (2005) An approach for GIS-based statistical landslide susceptibility zonation-with a case study in the Himalayas. Landslides 2(1):61-69

50. Pandit MK (2007) Carrying capacity study of Teesta Basin in Sikkim: executive summary and recommendations. Centre for Interdisciplinary Studies of Mountain and Hill Environment, Delhi University, Delhi

51. Chakraborty I, Ghosh S, Bhattacharya D, Bora A (2011) Earthquake induced landslides in the Sikkim-Darjeeling Himalayas-an aftermath of the 18th September 2011 Sikkim earthquake. Geological Survey of India, Kolkata

52. Environment information system (ENVIS) center Sikkim (2016) Natural resources atlas of Sikkim. http://www.sikenvis.nic.in/Datab ase/NaturalResources_790.aspx. Accessed 5 June 2018

53. Fernandez T, Irigaray C, El Hamdouni R, Chacón J (2003) Methodology for landslide susceptibility mapping by means of a GIS. Application to the Contraviesa area (Granada, Spain). Nat Hazards 30(3):297-308

54. Guzzetti F, Mondini AC, Cardinali M, Fiorucci F, Santangelo M, Chang KT (2012) Landslide inventory maps: new tools for an old problem. Earth Sci Rev 112(1-2):42-66

55. Youssef AM (2015) Landslide susceptibility delineation in the Ar-Rayth area, Jizan, Kingdom of Saudi Arabia, using analytical hierarchy process, frequency ratio, and logistic regression models. Environ Earth Sci 73(12):8499-8518

56. Ahmed B (2015) Landslide susceptibility mapping using multicriteria evaluation techniques in Chittagong Metropolitan Area, Bangladesh. Landslides 12(6):1077-1095
57. Akgun A, Dag S, Bulut F (2008) Landslide susceptibility mapping for a landslide-prone area (Findikli, NE of Turkey) by likelihoodfrequency ratio and weighted linear combination models. Environ Geol 54(6):1127-1143

58. Dai FC, Lee CF (2002) Landslide characteristics and slope instability modeling using GIS, Lantau Island, Hong Kong. Geomorphology 42(3-4):213-228

59. Gorsevski PV, Donevska KR, Mitrovski CD, Frizado JP (2012) Integrating multi-criteria evaluation techniques with geographic information systems for landfill site selection: a case study using ordered weighted average. Waste Manag 32(2):287-296

60. Pradhan AMS, Kim YT (2017) Spatial data analysis and application of evidential belief functions to shallow landslide susceptibility mapping at Mt. Umyeon, Seoul, Korea. Bull Eng Geol Env 76(4):1263-1279

61. Kannan M, Saranathan E, Anabalagan R (2013) Landslide vulnerability mapping using frequency ratio model: a geospatial approach in Bodi-Bodimettu Ghat section, Theni district, Tamil Nadu, India. Arab J Geosci 6(8):2901-2913

62. Shahabi H, Hashim M (2015) Landslide susceptibility mapping using GIS-based statistical models and Remote sensing data in tropical environment. Sci Rep 5:9899

63. Kriegler FJ, Malila WA, Nalepka RF, Richardson W (1969) Preprocessing transformations and their effects on multispectral recognition. Remote Sens Environ VI:97

64. Huang J, Zhou Q, Wang F (2015) Mapping the landslide susceptibility in Lantau Island, Hong Kong, by frequency ratio and logistic regression model. Ann GIS 21(3):191-208

65. Demir G, Aytekin M, Akgün A, Ikizler SB, Tatar O (2013) A comparison of landslide susceptibility mapping of the eastern part of the North Anatolian Fault Zone (Turkey) by likelihood-frequency ratio and analytic hierarchy process methods. Nat Hazards 65(3):1481-1506

66. Neogi S, Dasgupta S, Fukuoka M (1998) High P-T polymetamorphism, dehydration melting, and generation of migmatites and granites in the Higher Himalayan Crystalline Complex, Sikkim, India. J Petrol 39(1):61-99

67. Pradhan B, Youssef AM (2010) Manifestation of remote sensing data and GIS on landslide hazard analysis using spatial-based statistical models. Arab J Geosci 3(3):319-326

Publisher's Note Springer Nature remains neutral with regard to jurisdictional claims in published maps and institutional affiliations. 